\title{
GCU
}

Glasgow Caledonian

University

University for the Common Good

\section{Hydrological effect of vegetation against rainfall-induced landslides}

Gonzalez Ollauri, Alejandro; Mickovski, Slobodan B.

Published in:

Journal of Hydrology

DOI:

10.1016/j.jhydrol.2017.04.014

Publication date:

2017

Document Version

Author accepted manuscript

Link to publication in ResearchOnline

Citation for published version (Harvard):

Gonzalez Ollauri, A \& Mickovski, SB 2017, 'Hydrological effect of vegetation against rainfall-induced landslides', Journal of Hydrology, vol. 549, pp. 374-387. https://doi.org/10.1016/j.jhydrol.2017.04.014

\section{General rights}

Copyright and moral rights for the publications made accessible in the public portal are retained by the authors and/or other copyright owners and it is a condition of accessing publications that users recognise and abide by the legal requirements associated with these rights.

Take down policy

If you believe that this document breaches copyright please view our takedown policy at https://edshare.gcu.ac.uk/id/eprint/5179 for details of how to contact us. 
Authors: Alejandro Gonzalez-Ollauri ${ }^{1,2}$ and Slobodan B. Mickovski ${ }^{1}$

${ }^{1}$ School of Engineering \& Built Environment, Glasgow Caledonian University, Glasgow, UK

${ }^{2}$ Corresponding author: alejandro.ollauri@gcu.ac.uk $+44(0) 1413313433$ SEBE, Glasgow Caledonian University, Cowcaddens Road, G4 0BA Glasgow, UK 


\section{Abstract}

The hydrological effect of vegetation on rainfall-induced landslides has rarely been quantified and its integration into slope stability analysis methods remains a challenge. Our goal was to establish a reproducible, novel framework to evaluate the hydrological effect of vegetation on shallow landslides. This was achieved by accomplishing three objectives: (i) quantification in situ of the hydrological mechanisms by which woody vegetation (i.e. Salix sp.) might impact slope stability under wetting and drying conditions; (ii) to propose a new approach to predict plantderived matric suctions under drying conditions; and (iii) to evaluate the suitability of the unified effective stress principle and framework (UES) to quantify the hydrological effect of vegetation against landslides. The results revealed that plant water uptake was the main hydrological mechanism contributing to slope stability, as the vegetated slope was, on average, $12.84 \%$ drier and had matric suctions three times higher than the fallow slope. The plant-related mechanisms under wetting conditions had a minimal effect on slope stability. The plant aerial parts intercepted up to $26.73 \%$ of the rainfall and concentrated a further $10.78 \%$ of it around the stem. Our approach successfully predicted the plant-derived matric suctions and UES proved to be adequate for evaluating the hydrological effect of vegetation on landslides. Although the UES framework presented here sets the basis for effectively evaluating the hydrological effect of vegetation on slope stability, it requires knowledge of the specific hydro-mechanical properties of plant-soil composites and this in itself needs further investigation.

Keywords: hydrological, vegetation, willow, matric suction, landslide, slope stability 
1. Introduction

80

Rainfall-induced landslides are global phenomena that result in loss of human life and damage to property every year (Sidle and Bogaard, 2016). They are normally triggered by a decrease in the soil shear strength after heavy rainfall events on sloped terrain (Lu and Godt, 2013). As a consequence of the predicted intensification of the hydrological cycle due to climate change?? (Roderick et al., 2014), the likelihood of rainfall-induced landslides is expected to increase, making the implementation of mitigation and remediation measures a priority.

88 Vegetation has been proven to be an effective landslide mitigation measure, as it enhances the soil shear strength via a series of mechanical and hydrological effects (Norris et al., 2008). While the mechanical effect of vegetation on slope stabilisation has been extensively studied (Wu et al. 1979; Mickovski et al., 2009; Bordoni et al., 2016), the plant hydrological effect, although acknowledged (Simon and Collison, 2002), has rarely been quantified and reported in the scientific literature (Stokes et al., 2014). Information on how vegetation performs hydrologically could significantly contribute to the effective and sustainable selection of plant species (Duan et al., 2016; McVicar et al., 2010) to reduce the likelihood of slope instability and the risks associated with it (Lu and Godt, 2013; Fell et al., 2005).

The hydrological effect of vegetation results from the interaction of different mechanisms occurring at the soil-plant-atmosphere continuum (Rodriguez-Iturbe and 100 Porporato, 2004). These could be broadly divided into wetting and drying. During a 101 rainfall event (wetting), vegetation may regulate the amount of water reaching the 102 soil. The aerial parts (e.g. tree canopy) can intercept part of the precipitation (Llorens 
and Domingo, 2007) creating an "umbrella effect" that could attenuate the amount of rainfall available to infiltrate into the soil. However, part of the rainwater will reach the soil by flowing along the stem (i.e. stemflow; Levia and Germer, 2015). Stemflow could have negative consequences upon slope stability as the water funnels around the

107 tree base and enters the soil as a jet through the root channels (i.e. bypass flow; e.g.

108 Liang et al., 2011). Bypass flow may induce changes in the soil stress-state (Lu and 109 Godt, 2013) or facilitate the formation of perched water tables at depth (e.g. Simon 110 and Collison, 2002).

111 The drying mechanisms are those that tend to reduce the degree of saturation of 112 the soil after a rainfall event. Vegetation may support the drainage of water from the 113 root zone by loosening the soil and opening preferential flow channels via the root 114 system (Liang et al., 2011). However, the most acknowledged drying mechanism is 115 the plant water uptake (e.g. Laio, 2006), which involves the withdrawal of water from 116 the soil to satisfy plant physiological needs and transpiration into the atmosphere (i.e. 117 evapotranspiration; e.g. Rodriguez-Iturbe and Porporato, 2004). Plant transpiration is 118 a markedly seasonal process in temperate climates (e.g. Wever et al., 2002) and the 119 shading effect produced by the vegetation cover can further reduce direct soil 120 evaporation (e.g. Raz-Yaseef et al., 2010). Nonetheless, plant transpiration is meant to 121 generate a water flow exiting the soil (Laio, 2006). This would reduce the degree of 122 soil saturation aas well as the pore-water pressures (i.e. increasing the matric suction), 123 potentially increasing the soil shear strength (Vanapalli et al., 1996; Gonzalez-Ollauri 124 and Mickovski, 2017). To date, models predicting the effect of plant transpiration on 125 the soil stress-state are severely lacking (e.g. Scanlan, 2009).

126 The mechanisms by which vegetation may contribute hydrologically to slope 127 stability have been investigated before (for review see Stokes et al., 2014). A 
recognised challenge, however, is their integration into slope stability analysis methods. The unified effective stress principle (UES; Lu and Likos, 2004) and

130 framework (Lu and Griffiths, 2006; Lu and Godt, 2008; Lu et al., 2010), known in

131 soil mechanics, permits the assessment of the state of stress in steep soil-mantled 132 hillslopes under a range of water flow conditions - i.e. infiltration (wetting) or 133 evaporation (drying). Considering these, the UES quantifies the resulting soil matric 134 suction (Lu and Griffiths, 2006) and the associated suction stress (Lu et al., 2010); 135 defined as the mechanical equivalent of the soil inter-particle stress. The suction stress 136 has a negative value and affects positively (i.e. increases) the soil strength as its value 137 becomes more negative ( $\mathrm{Lu}$ and Godt, 2013). The intimate relationship of the suction 138 stress to the matric suction (Lu and Likos, 2004, 2006) makes the former an ideal 139 proxy to quantify plant-derived hydrological effects on slope stability (Gonzalez140 Ollauri and Mickovski, 2017). Vegetation affects the water flow conditions through 141 the different mechanisms discussed above (i.e. rainfall interception, stemflow, water 142 uptake) and, hence, the soil matric suction. However, this effect has not been tested 143 before on soils under woody vegetation using field-derived information and the UES. 144 The UES was conceived for soil only, while the plant roots form a composite material 145 with the soil (Thorne, 1990). This material is likely to behave hydro-mechanically 146 differently from a fallow soil (Gonzalez-Ollauri and Mickovski, 2017) because the 147 root systems will alter, among others, the pore size and distribution (Scanlan, 2009), 148 the water retention dynamics (Carminati et al., 2010; Scholl et al., 2014) and the 149 permeability of the soil (Vergani and Graf, 2015). The aim of this study was to establish a reproducible novel framework for the 151 evaluation of the hydrological effect of vegetation against rainfall-induced landslides. 152 To achieve this, the following three objectives were set: 
(i) To quantify in situ the hydrological mechanisms by which woody vegetation (i.e. Salix sp.) may impact the stability of a small-scale, landslide-prone, temperate humid hillslope under wetting and drying conditions.

(ii) To propose a new simplified approach to predict the plant-derived matric suction under drying conditions.

(iii) To evaluate the suitability of the unified effective stress principle and framework for quantification of the hydrological effect of vegetation against rainfall-induced landslides.

2. Study site and plant individuals

The study site is located adjacent to Catterline Bay, Aberdeenshire, UK (WGS84 Long: -2.21 Lat: 56.90; Fig. 1a), within the temperate humid climate zone (Cgc: subpolar oceanic climate; Köppen, 1884). The mean annual temperature at the site is $8.9^{\circ} \mathrm{C}$ and the mean annual rainfall is $565.13 \mathrm{~mm}(2011-2014$; Gonzalez-Ollauri and Mickovski, 2016). The precipitation at the site is characterised by frequent, lowintensity rainfall events (Gonzalez-Ollauri and Mickovski, 2016). Well-drained (saturated hydraulic conductivity $\left(K_{s}\right): 5.82 \times 10^{-05} \mathrm{~m} \mathrm{~s}^{-1}$ ), shallow (ca. $600 \mathrm{~mm}$ ), sloped $\left(25-50^{\circ}\right)$, and landslide-prone silty sands (sand: $79.82 \%$; silt: $5.85 \%$; clay: $3.08 \%)$ overlie conglomerate rock. The topsoil at the site $(0-400 \mathrm{~mm}$ below ground level, b.g.1.) has a mean dry bulk density of $0.86 \mathrm{~g} \mathrm{~cm}^{-3}$, a drained apparent cohesion of $33.4 \mathrm{kPa}$, a mean angle of internal friction of $22^{\circ}$ and a mean organic matter content of $5.57 \%$.

Two adjacent $10 \mathrm{~m}$ × $20 \mathrm{~m}$ hillslope transects with similar slope gradient (mean slope gradient: $25.6^{\circ}$; Figs. $1 \mathrm{~b}$, c) were available for studying the hydrological 

winter of 2013. Five willow individuals (two Salix caprea and three Salix viminalis) representative of the tree stand present in our study site (Fig.1) were selected for study from the willow-vegetated transect (Table 1).

Figure 1. (a) Study site location and monitoring area (yellow frame) (b) Monitoring points layout in the vegetated $(\mathrm{X})$ and fallow $(\mathrm{O})$ slope transect. LT: lower toe; UT: upper toe; LC: lower crest; UC: upper 190 crest (c) Detailed view of the two monitored transects. Source aerial image: GetMapping, 2014.

191

Table 1. Tree metrics for the different willow individuals selected for study. $H$ : tree height; $D B H$ : diameter at breast height; $A c$ : canopy-crown area; $L A I$ : leaf area index; Ma: mean aboveground biomass estimated from allometric equations for $S$. viminalis (Nordh and Verwijst, 2004) and $S$. caprea (Muukkonen and Makipaa, 2006) using $H$ and $D B H$ as inputs.. Individuals on which rainfall interception was studied.

193

\begin{tabular}{ccccccc}
\hline Species & Individual & $H(\mathrm{~m})$ & $D B H(\mathrm{~m})$ & $A c\left(\mathrm{~m}^{2}\right)$ & $L A I$ & $M a\left(\mathrm{~g} \mathrm{~m}^{-2}\right)$ \\
\hline S. viminalis & SV I $^{*}$ & 2.84 & 0.44 & 6.54 & 3.26 & 354.68 \\
S. viminalis & SV II $^{*}$ & 3.65 & 0.39 & 4.24 & 2.67 & - \\
S. viminalis & SV III & 13.04 & 0.37 & 13.14 & 1.56 & - \\
S. caprea & SC I & 4.93 & 0.20 & 13.05 & 3.63 & 2373.18 \\
S. caprea & SC II & 4.52 & 0.11 & 8.77 & 4.46 & - \\
\hline
\end{tabular}
under wetting and drying conditions

\subsubsection{Wetting conditions}

Stemflow volume was measured for the five selected willow individuals (Table 1)

200 during the growing (July - October, 2014) and dormant seasons (November 2014 - 
201 February 2015), respectively. For this, PVC stemflow gutters (Fig. 2a) were installed 202 at breast height, spiralling around each tree stem and discharging into $25 \mathrm{~L}$ plastic 203 containers. The stemflow volume $\left(\mathrm{m}^{3}\right)$ was scaled with the canopy-crown area $(A c$; $204 \mathrm{~m}^{2}$; Table 1) and regressed against the gross rainfall $\left(\mathrm{P}_{\mathrm{g}}\right.$; Deguchi et al., 2006) in the 205 statistical software R v.3.2.1 (R Core Team, 2015). The magnitude of gross rainfall $206\left(\mathrm{P}_{\mathrm{g}}\right)$ was averaged from the volumes collected in 5 exposed rain gauges distributed 207 randomly over the study site and consisting of $75 \mathrm{~mm}$ diameter plastic funnels 208 attached to $2000 \mathrm{ml}$ PVC bottles (Fig. 2a).

Figure 2. a) Field setup for the quantification of hydrological mechanisms of willow affecting slope stability under wetting - i.e. throughfall and stemflow b) Field setup for the quantification of hydrological mechanisms of willow affecting slope stability under drying - i.e. evapotranspiration (ETP) or plant-water uptake. from the entwined canopies in the stand. The interception was quantified during the growing (July - October, 2014) and dormant season (November 2014 - February 2015), respectively, by collecting the rainfall passing through the canopy (i.e.

217 throughfall; Fig. 2a) into three different rain gauges placed below the canopy and at 218 different distances from the stem for each studied individual (Table 1). The average of 219 the water volumes collected by the undercanopy rain gauges was compared against 220 the volume of gross rainfall $\left(\mathrm{P}_{\mathrm{g}}\right)$. Linear regression models were fitted between the 221 registered throughfall and gross rainfall volumes in R v.3.2.1 (i.e. revised Gash 222 model; van Dijk and Bruijnzeel, 2001; Deguchi et al., 2006). The canopy storage 223 capacity was appraised from the fitted regression lines (Leyton et al., 1967). The 
rainfall interception loss was estimated to be the difference between the gross rainfall and throughfall.

\subsubsection{Drying conditions}

The plant water uptake from the soil was quantified as soil matric suction $\left(u_{a^{-}}\right.$ $u_{w} ; \mathrm{kPa} ; u_{a}$ : pore-air pressure $u_{w}$ : pore-water pressure; Fig. 2b; e.g. Persson, 1995) and soil volumetric moisture content $\left(\theta_{v}\right)$ differences between the vegetated and the fallow slope transect. Daily measurements of $u_{a}-u_{w}$ and $\theta_{v}$ were taken with a field tensiometer (Irrometer ${ }^{\circledR}$; Fig. 2b) and a moisture profile probe (Delta- ${ }^{\circledR}$ ), respectively, during the period of maximum atmospheric water demand $\left(7^{\text {th }} \mathrm{July}-18^{\text {th }}\right.$ August, 2014). $u_{a}-u_{w}$ and $\theta_{v}$ measurements were collected from within the soil-root zone (0 - $400 \mathrm{~mm}$ b.g.1.; Tardio et al., 2016) at four different slope points (i.e. LT:

235 lower toe; UT: upper toe; LC: lower crest; UC: upper crest), spaced every $2 \mathrm{~m}$ over each slope transect (Fig. 1b). The matric suction readings were collected at a single soil depth (350 mm b.g.l.) at the four slope points, while the moisture readings were collected at 300 and $400 \mathrm{~mm}$ b.g.l. at the four slope points.

3.2. Prediction of plant-derived matric suction under drying conditions

\subsubsection{Approach}

To predict the plant-derived $u_{a}-u_{w}$ under drying conditions (Eq.1; Table 2), we

244 modified an existing closed-form equation designed to predict $u_{a}$ - $u_{w}$ under variable 245 steady-state water flow situations (i.e. negative sign flow: infiltration; positive sign 246 flow: evaporation) in isotropic soil materials (Eq. 2; Table 2; Lu and Griffiths, 2006;

247 for numerical derivation see Lu and Godt, 2013). Eq.2 (Table 2) is derived from the 248 integration of Darcy's law over time and space using the soil water characteristic 
curve (SWCC) and the hydraulic conductivity function (HCF). We modified the original equation by: (a) replacing $K s$ by the unsaturated hydraulic conductivity $(K(\theta)$;

251 Eq.6; Table 2), or $\mathrm{HCF}$, because the soil will de-saturate as it drains or dries and 252 because the plant water uptake will be negligible in waterlogged soils (Rodriguez-

253 Iturbe and Porporato, 2004); and (b) introducing the canopy-crown area $\left(A c ; \mathrm{m}^{2}\right.$;

254 Table 1) as a scaling parameter, because the entire plant crown may contribute to soil 255 suction through plant water uptake if a top-down uptake approach is adopted (Shukla, 256 2014). Eq.1 (Table 2) assumes steady plant transpiration rates within the whole root 257 zone (i.e. $0-400 \mathrm{~m}$ b.g.l)

\subsubsection{Parameterisation}

To implement Eq.1 (Table 2), knowledge of the potential daily plant

260 transpiration rate $\left(E_{t p} ; \mathrm{m} \mathrm{d}^{-1} \mathrm{~m}^{-2}\right.$; Eq.3; Table 2$)$ and the soil hydro-mechanical 261 parameters ( $\alpha$ : inverse of air-entry pressure, $\mathrm{kPa}^{-1} ; n$ : pore-size distribution parameter, 262 unitless) is needed.

263 To estimate $E_{t p}$ (Eq.3; Table 2$)$, the potential daily evapotranspiration rate $\left(E_{u}\right.$; $264 \mathrm{~m} \mathrm{~d}^{-1} \mathrm{~m}^{-2}$ ) was calculated using the Priestly and Taylor (1972) method. For this, we 265 employed meteorological records (i.e. daily air temperature, atmospheric pressure, 266 and sunshine duration) retrieved from an in situ weather station (voor de Porte, 2011). 267 The input variables to estimate $E_{u}$ (i.e. daily solar radiation, psychrometric constant, 268 and slope of the saturated vapor pressure at mean air temperature) were calculated as 269 specified in Allen et al. (1998). The extension suggested by Savabi and Williams 270 (1995) was adopted to account for different vegetation covers in terms of the leaf area 271 index (LAI; Eq.4; Table 2) and to obtain $E_{t p}$ from $E_{u}$ (Eq.3; Table 2). 
Table 2. List of equations used in this study.

\begin{tabular}{|c|c|c|c|c|c|}
\hline Definition & Equation & $\mathrm{N}^{\mathrm{o}}$ & Parameters & Units & Equation source \\
\hline \multirow{8}{*}{$\begin{array}{l}\text { Vegetated soil matric } \\
\text { suction under drying } \\
\text { conditions }\end{array}$} & \multirow{8}{*}{$u_{a}-u_{w}=A c\left[\frac{-1}{\alpha} \ln \left(\left(1+\frac{E_{t p}}{K(\theta i)}\right) e^{-\gamma w \alpha z}-\frac{E_{t p}}{K(\theta i)}\right)\right]$} & \multirow[t]{8}{*}{ Eq.1 } & $\mathrm{u}_{\mathrm{a}}-\mathrm{u}_{\mathrm{w}}:$ matric suction & $\mathrm{kPa}$ & This study \\
\hline & & & Ac: canopy-crown area & $\mathrm{m}^{2}$ & \\
\hline & & & $\alpha:$ inverse air-entry pressure & $\mathrm{kPa}^{-1}$ & \\
\hline & & & $\mathrm{E}_{\mathrm{tp}}:$ potential plant transpiration rate & $\mathrm{m} \mathrm{s}^{-1} \mathrm{~m}^{-2}$ & \\
\hline & & & $\mathrm{K}\left(\theta_{\mathrm{i}}\right)$ : unsaturated hydraulic conductivity & $\mathrm{m} \mathrm{s}^{-1}$ & \\
\hline & & & $\theta_{\mathrm{i}}:$ soil volumetric moisture content & $/ 1$ & \\
\hline & & & $\gamma_{\mathrm{w}}:$ unit weight of water & $\mathrm{kPa} \mathrm{m}^{-1}$ & \\
\hline & & & $\begin{array}{l}\text { z: vertical coordinate, upward positive -i.e.soil } \\
\text { depth from lower soil boundary (e.g. water } \\
\text { table) }\end{array}$ & $\mathrm{m}$ & \\
\hline \multirow[t]{2}{*}{ Soil matric suction } & \multirow[t]{2}{*}{$u_{a}-u_{w}=\frac{-1}{\alpha} \ln \left(\left(1+\frac{q}{K s}\right) e^{-\gamma w \alpha z}-\frac{q}{K s}\right)$} & \multirow[t]{2}{*}{ Eq.2 } & $\begin{array}{l}\text { q: water flow (infiltration: negative sign; } \\
\text { evapotranspiration: positive sign) }\end{array}$ & $\mathrm{m} \mathrm{s}^{-1}$ & Lu and Griffiths (2006) \\
\hline & & & Ks: saturated hydraulic conductivity & $\mathrm{m} \mathrm{s}^{-1}$ & \\
\hline \multirow[t]{2}{*}{ Plant transpiration } & \multirow{2}{*}{$E_{t p}=\left(1-\frac{E_{s p}}{E_{u}}\right) E_{u}$} & \multirow[t]{2}{*}{ Eq.3 } & $\mathrm{E}_{\mathrm{sp}}$ : potential direct soil evaporation rate & $\mathrm{m} \mathrm{s}^{-1} \mathrm{~m}^{-2}$ & Savabi and Williams (1995) \\
\hline & & & $\mathrm{E}_{\mathrm{u}}:$ potential evapotranspiration rate & $\mathrm{m} \mathrm{s}^{-1} \mathrm{~m}^{-2}$ & \\
\hline Direct soil evaporation & $E s p=E u e^{-0.4 L A I}$ & Eq.4 & LAI: leaf area index & Unitless & Savabi and Williams (1995) \\
\hline \multirow{3}{*}{$\begin{array}{l}\text { Soil water characteristic } \\
\text { curve }^{c}\end{array}$} & \multirow{3}{*}{$\theta i=\theta r+(\theta s-\theta r)\left(\frac{1}{\left(1+\left(\alpha\left(u_{a}-u_{w}\right)\right)^{n}\right)^{1-\frac{1}{n}}}\right.$} & \multirow[t]{3}{*}{ Eq.5 } & $\theta_{\mathrm{r}}:$ residual soil volumetric moisture content & $/ 1$ & Van Genuchten (1980) \\
\hline & & & $\theta_{\mathrm{r}}$ : saturated soil volumetric moisture content & $/ 1$ & \\
\hline & & & $\mathrm{n}$ : pore size distribution parameter & Unitless & \\
\hline $\begin{array}{l}\text { Hydraulic conductivity } \\
\text { function }\end{array}$ & $K(\theta i)=K s\left(\frac{\theta i}{\theta s}\right)^{n}$ & Eq.6 & & & Brooks and Corey (1964) \\
\hline Suction stress function & $\sigma^{s}=-\frac{u_{a}-u_{w}}{\left(1+\alpha\left(u_{a}-u_{w}\right)^{n}\right)^{\frac{n-1}{n}}}$ & Eq.7 & $\sigma^{\mathrm{s}}$ : suction stress & $\mathrm{kPa}$ & Lu et al. (2010) \\
\hline \multirow{5}{*}{$\begin{array}{l}\text { Soil shear strength (unified } \\
\text { effective stress principle) }\end{array}$} & \multirow[t]{5}{*}{$\tau=c^{\prime}+\left(\sigma-u_{a}-\sigma^{s}\right) \tan \phi^{\prime}$} & \multirow[t]{5}{*}{ Eq.8 } & $\tau:$ soil shear strength & $\mathrm{kPa}$ & Lu and Likos (2004) \\
\hline & & & c': soil effective cohesion & $\mathrm{kPa}$ & \\
\hline & & & $\sigma:$ normal stress & $\mathrm{kPa}$ & \\
\hline & & & $\mathrm{u}_{\mathrm{a}}:$ pore-air pressure & $\mathrm{kPa}$ & \\
\hline & & & $\phi^{\prime}:$ soil inter-particle angle of internal friction & Degrees & \\
\hline \multirow[t]{2}{*}{ Factor of Safety } & \multirow{2}{*}{$F o S=\frac{c^{\prime}+\left(\sigma(z)-\sigma^{S}(z)\right) \tan \phi^{\prime}}{\sigma(z) \sin \beta \cos \beta}$} & \multirow[t]{2}{*}{ Eq.9 } & FoS: factor of safety & $/ 1$ & Lu and Godt (2008) \\
\hline & & & $\beta$ : slope gradient or angle & Degrees & \\
\hline \multirow[t]{4}{*}{ Normal stress } & \multirow{4}{*}{$\sigma(z)=(\gamma s(H w t-z)+W v) \cos ^{2} \beta$} & \multirow[t]{4}{*}{ Eq.10 } & $\sigma(\mathrm{z})$ : normal stress with soil depth & $\mathrm{kPa}$ & This study \\
\hline & & & $\gamma_{\mathrm{s}}:$ soil moist unit weight & $\mathrm{kPa} \mathrm{m}^{-1}$ & \\
\hline & & & $\mathrm{H}_{\mathrm{wt}}$ : water table (lower soil boundary) height & $\mathrm{m}$ & \\
\hline & & & $\mathrm{W}_{\mathrm{v}}$ : vegetation surcharge & $\mathrm{N} \mathrm{m}^{-2}$ & \\
\hline \multirow[t]{3}{*}{ Bypass flow rate } & \multirow[t]{3}{*}{$q_{b y}=A c S t / t_{r}$} & \multirow[t]{3}{*}{ Eq.11 } & $\mathrm{q}_{\mathrm{by}}:$ bypass flow rate & $\mathrm{m} \mathrm{s}^{-1}$ & This study \\
\hline & & & St: stemflow volume per unit area of tree-crown & $\mathrm{m}^{3} \mathrm{~m}^{-2}$ & \\
\hline & & & $\mathrm{t}_{\mathrm{r}}:$ rainfall duration & $\mathrm{s}$ & \\
\hline \multirow[t]{3}{*}{ Evaporative soil depth } & \multirow[t]{3}{*}{$d_{x}=0.09-0.0077 C l+0.000006 S a^{2}$} & \multirow[t]{3}{*}{ Eq.12 } & $\mathrm{d}_{\mathrm{x}}:$ maximum evaporative soil depth & $\mathrm{m}$ & Savabi and Williams (1995) \\
\hline & & & $\mathrm{Cl}$ : percentage of clay in soil & $\%$ & \\
\hline & & & Sa: percentage of sand in soil & $\%$ & \\
\hline
\end{tabular}


The soil hydro-mechanical parameters ( $\alpha$ and $n)$ under vegetated and fallow

3 soil conditions, respectively, were retrieved by fitting the soil water characteristic

4 curve (SWCC; Eq.5; Table 2; van Genuchten, 1980) for the drying path (Lu and

5 Likos, 2004) in R v.3.2.1. To fit the SWCC, we examined the relationship between

6 the coupled measurements of matric suction $\left(u_{a}-u_{w} ; \mathrm{kPa}\right)$ and soil volumetric moisture

7 content $\left(\theta_{v} ; \%\right)$ collected in situ over time (see 3.1.2) (e.g. Lu and Godt, 2013). Then,

8 Eq.5 (Table 2) was fitted iteratively to the observed data points by assigning values to

$9 \alpha$ and $n$ in Eq.5 until the maximum goodness of fit $\left(\mathrm{R}^{2}\right)$ was achieved. Once the soil

10 hydro-mechanical parameters were estimated, HCF (Eq.6; Table 2; Brooks and

11 Corey, 1964) could be implemented in Eq.1 (Table 2) before proceeding with the 12 plant-derived $u_{a}-u_{w}$ predictions.

13 The predictions of $u_{a}-u_{w}$ under vegetated soil were carried out using Eq.1

14 (Table 2) for the same days on which in situ $u_{a}-u_{w}$ records were taken at the four 15 different slope positions (see 3.1.2). For the $u_{a}-u_{w}$ predictions, the soil moisture was 16 assumed to be constant and at field capacity (i.e. $\theta_{v}=0.23$ ), while the soil depth $(\mathrm{z})$ 17 was fixed at $350 \mathrm{~mm}$ b.g.l. The mean $A c$ among the assessed willow individuals 18 (Table 1) was employed for the lower toe (LT), upper toe (UT) and lower crest (LC) 19 positions. For the upper crest (UC), the canopy area of the individual adjacent to the 20 tensiometer was used (i.e. $A c=3.74 \mathrm{~m}^{2}$ ).

3.3. Evaluation of willow hydrological effect on slope stability using the unified effective stress principle 
Figure 3. Conceptual model for evaluating the hydrological effect of vegetation on slope stability(after Gonzalez-Ollauri and Mickovski, 2014). The forcing functions are portrayed by thick arrows and the system state variables by boxes.

We employed an existing conceptual model to evaluate the hydrological effect of willow on slope stability (Gonzalez-Ollauri and Mickovski, 2014; Fig. 3). This model considers the hydrological mechanisms quantified at the soil-plant-atmosphere interface (i.e. rainfall interception, stemflow, and plant water uptake; see 3.1) as driving functions that induce changes on the system state variables - the soil matric suction (Eq. 1 and Eq. 2; Table 2) and degree of saturation (intrinsically related to SWCC; Eq.5; Table 2). On the basis of the soil hydro-mechanical parameters (i.e. $\alpha$ and $n$; see 3.2.2), the model defines the stress-state in the soil and, ultimately, the slope stability (Figs. 3 and 4). The stress-state in the soil is depicted by the suction stress ( $\sigma^{s}$; Eq.7; Table 2; Lu et al., 2010) featured in Coulomb's law (e.g. Head and Epps, 2011) for the estimation of the soil shear resistance ( $\tau$; Eq.8; Table 2) under variable soil saturation conditions (i.e. unified effective stress principle; UES; Lu and Likos, 2004). The slope stability was evaluated with the infinite slope limit equilibrium method (LEM; e.g. Craig, 2004). This estimates a factor of safety (i.e. FoS = resisting forces/driving forces; Eq.9; Table 2; Lu and Godt, 2008) and includes the UES within the resisting forces (Eq.8; Table 2). The driving forces are depicted by the normal stress ( $\sigma(z)$; Eq. 10; Table 2), which includes the vegetation surcharge

$45\left(W_{v}\right.$; Table 2$)$, and the slope gradient $(\beta)$. Herein, $W_{v}$ was derived from the vegetation aboveground biomass (Ma; Table 1). 
We tested the approach described in 3.3.1 (Fig. 3) using four discrete

49 meteorological events (i.e. two events under wetting and drying conditions, 50 respectively) for vegetated and fallow soil covers, and under limit equilibrium

51 conditions (aimed at stressing the hydrological effect of vegetation under critical slope

52 stability conditions; Lu and Godt, 2013). In all of the scenarios, the slope inclination (

$53 \beta)$ was taken as $45^{\circ}$, the angle of internal friction as $22^{\circ}$, and the soil at saturation $(c=0$

$54 \mathrm{kPa}$ ), mimicking the onset of a rainfall-induced landslide.

55 a) Wetting conditions

Two rainfall episodes of different intensity were considered: (S1) the maximum rainfall event registered during the monitoring period - i.e. $15.6 \mathrm{~mm}$ of cumulative rainfall during $10 \mathrm{~h}$; and (S2) the maximum recorded precipitation event at the study site which, presumably, triggered multiple shallow landslide events - i.e. $42.2 \mathrm{~mm}$ of cumulative rainfall during $10 \mathrm{~h}$.

The throughfall and stemflow derived from each rainfall event were evaluated under growing and dormant states, using the regression models obtained for each mechanism and season (see 3.1.1). Both mechanisms were treated differently in terms of the infiltration process they triggered (Fig. 4). Throughfall water was assumed to infiltrate the soil as a piston flow once ponding formed on the ground surface (i.e. Green \& Ampt model; Mein and Larson, 1973; see Gonzalez-Ollauri and Mickovski, 2014). The piston flow was assumed to saturate the soil (i.e. $u_{a}-u_{w}=0 \mathrm{kPa}$ ) as the wetting front travelled down the soil profile (Neitsch et al., 2011). The same infiltration process was considered for the fallow soil (Fig. 4). The stemflow water, however, was assumed to bypass the soil-root zone (Liang et al. 2011) as a jet flow without considering the soil anisotropy produced by the root system. Thus, stemflow 
water would result in a water flow that infiltrates the root zone at a steady rate ( $q_{b y}$; Eq.11; Table 2), and produces changes in the soil stress-state as indicated in Fig.4. Eq.11 (Table 2) assumed that the entire tree-crown contributed to the stemflow. The formation of perched water tables in depth was neglected, and hydrostatic conditions (i.e. $\mathrm{q}=0 \mathrm{~m} \mathrm{~s}^{-1}$ ) were assumed to be below the wetting front.

Figure 4. Workflow diagram for the evaluation of the soil stress-state and corresponding slope stability.

b) Drying conditions

Two different evapotranspiration events were considered. These corresponded to the days of maximum and minimum atmospheric demand registered during the monitoring period (i.e. July, $7^{\text {th }}-$ August, $18^{\text {th }}, 2014$ ). The soil moisture content was assumed to be constant throughout the soil profile and at field capacity (i.e. $\theta_{v}=0.23$ ). For the vegetated soil, the soil stress-state was evaluated using Eq.1 (Table 2; Fig. 4) assuming that the whole root system (0-400 $\mathrm{mm}$ b.g.l) contributed to $\mathrm{E}_{\mathrm{tp}}$ (i.e. steady plant transpiration rate). Hydrostatic conditions were considered to be?? below the root zone (i.e. $E_{t p}=0 \mathrm{~m} \mathrm{~s}^{-1}$ ).

For fallow soil, the soil stress-state was evaluated using Eq.1 (Table 2; Fig. 4), with $A c$ equal to $1 \mathrm{~m}^{2}$, and the potential soil evaporation ( $E_{s p}$; Eq.4; Table 2$)$ was considered to be the driving function. The evaporative soil depth $\left(d_{x}\right)$ was estimated to be a function of the soil particle size distribution (Eq.12; Table 2; Savabi and Williams, 1995). Hydrostatic conditions were assumed to be?? below $d_{x}$. 
The statistical differences between the fitted regression models for the throughfall and stemflow were examined by estimating the t-statistic at the $95 \%$ and 99\% confidence levels (Paternoster, 1998).

The statistical differences between the vegetated and fallow transects, and among the slope transect positions (i.e. LT, UT, LC, UC), in terms of $u_{a}-u_{w}$ and $\theta_{v}$ 101 were evaluated with Kruskal-Wallis $\left(\chi^{2}\right)$ tests at the $95 \%$ and $99 \%$ confidence levels 102 on the basis of the degrees of freedom (df) and after pertinent statistical distribution 103 testing. When statistically significant differences were found, the differences within 104 the groups were assessed with Wilcoxon tests (W). The $\theta_{v}$ differences between the 105 two evaluated soil depths (i.e. 300 and $400 \mathrm{~mm}$ b.g.l) were assessed in the same 106 manner. The slope stability (FoS) differences between the considered treatments (i.e. 107 vegetated vs. fallow and wetting vs. drying) were evaluated using Kruskal-Wallis and 108 Wilcoxon tests.

The statistical differences between the observations and predictions (i.e. 110 goodness of fit) for the plant-derived soil matric suction under drying conditions were 111 analysed with F-tests (i.e. variance test). Additionally, ARIMA (autoregressive 112 integrated moving average) models were fitted to each time series (i.e. observed and 113 predicted) after carrying out autocorrelation tests (Cowpertwait and Metcalfe, 2009).

114 The models were then compared on the basis of AIC (Akaike information criterion). stability under wetting and drying conditions 4.1.1. Wetting conditions 
124 with the gross rainfall $\left(\mathrm{P}_{\mathrm{g}}\right)$ in all cases. S. viminalis showed a positive rainfall 125 interception capacity for the growing (S1: 26.73\%; S2:22.03\%) and dormant 126 (S1:8.91\%; S2:2.25\%) seasons under both rainfall scenarios (Table 3). S. caprea, 127 however, only presented a positive rainfall interception capacity for the dormant 128 season under both rainfall scenarios (S1:16.73\%; S2:16.27\%; Table 3). The overall 129 canopy storage capacity was 0.72 and 0.41 for $S$. viminalis and S.caprea, respectively.

130 There were no statistical differences in throughfall between the two willow species 131 for the global fitted models (i.e. using all monitoring points; $\mathrm{t}=0.84, \mathrm{df}=48, \mathrm{p}>0.05$ ).

132 However, significant differences between the growing and dormant seasons in terms 133 of throughfall were observed for $S$. caprea $(\mathrm{t}=2.61, \mathrm{df}=3, \mathrm{p}<0.05)$. during the growing and dormant seasons for (a) interception, Salix viminalis (b) interception, Salix caprea (c) stemflow, Salix viminalis (d) stemflow, Salix caprea. Global fit: linear regression for the entire data set. Data points are derived from the cumulative rainfall belonging to discrete rainfall events (i.e. data points closer to origin; $\mathrm{P}_{\mathrm{g}}<20 \mathrm{~mm}$ ) and multiple rainfall events combined (i.e. data points farther from the origin; $\mathrm{P}_{\mathrm{g}}>20 \mathrm{~mm}$ ).

The water volume concentrated around the stem was higher for S. caprea,

141 reaching volumes beyond $45 \mathrm{~L}(10.78 \%$ of rainfall) under the heavy rainfall scenario

142 (S2) for both seasons (Table 3). The stemflow showed significant differences between 143 the two willow species for the fitted global regressions $(t=2.95, d f=48, p<0.01)$.

144 Seasonal differences were also observed for the two willow species (S. viminalis: $145 \mathrm{t}=6.86, \mathrm{df}=6, \mathrm{p}<0.01 ;$ S. caprea: $\mathrm{t}=2.07, \mathrm{df}=11, \mathrm{p}<0.05)$. The bypass flow rates 146 derived from the stemflow under the two considered rainfall scenarios (S1 and S2) are 147 shown in Table 3. 
149 Table 3. Throughfall $(\mathrm{Th})$ and stemflow $(\mathrm{St})$ linear relationships with gross rainfall $\left(\mathrm{P}_{\mathrm{g}}\right)$, and predicted outcomes for rainfall interception $\left(\mathrm{i}_{\mathrm{x}}\right)$, stemflow volume $\left(\mathrm{St}_{\mathrm{x}}\right)$ 150 and bypass flow rate $\left(\mathrm{q}_{\mathrm{by}-\mathrm{x}}\right)$ under the two rainfall scenarios considered - i.e. S1: $15.6 \mathrm{~mm}$ during $10 \mathrm{~h} ; \mathrm{S} 2: 42.2 \mathrm{~mm}$ during $10 \mathrm{~h}$. $\mathrm{R}^{2}$ : regression lines goodness of fit. 151 Global fit: linear regression fitted with every monitoring data.

\begin{tabular}{|c|c|c|c|c|c|c|c|c|c|c|c|c|}
\hline & & & Fitted & & & cted & Fitted & & & & edicted & \\
\hline Species & Individual & Season & Throughfall & $\mathrm{R}^{2}$ & $\begin{array}{l}\text { is1 }_{\text {s. }}(\mathrm{mm})\end{array}$ & $\begin{array}{c}\text { is }_{\text {s }} \\
(\mathrm{mm})\end{array}$ & Stemflow & $\mathrm{R}^{2}$ & $\begin{array}{l}\text { Sts1 } \\
\text { (L) }\end{array}$ & $\mathrm{St}_{\mathrm{S} 2}(\mathrm{~L})$ & $\begin{array}{l}\mathrm{q}_{\mathrm{by}-\mathrm{S1}} \\
\left(\mathrm{m} \mathrm{s}^{-1}\right)\end{array}$ & $\begin{array}{l}\mathrm{q}_{\mathrm{by}-\mathrm{S} 2} \\
\left(\mathrm{~m} \mathrm{~s}^{-1}\right)\end{array}$ \\
\hline S. viminalis & SV I & & $\mathrm{Th}=1.42 \mathrm{P}_{\mathrm{g}}-9.09$ & 0.89 & & & $\mathrm{St}=0.01 \mathrm{P}_{\mathrm{g}}+0.03$ & 0.72 & & & & \\
\hline S. viminalis & SV II & & $\mathrm{Th}=0.61 \mathrm{P}_{\mathrm{g}}-1.21$ & 0.93 & & & $\mathrm{St}=0.06 \mathrm{P}_{\mathrm{g}}-0.10$ & 0.82 & & & & \\
\hline S. viminalis & SV III & & - & - & & & $\mathrm{St}=0.05 \mathrm{P}_{\mathrm{g}}-0.12$ & 0.89 & & & & \\
\hline S. viminalis & & Growing & $\mathrm{Th}=0.81 \mathrm{P}_{\mathrm{g}}-1.21$ & 0.68 & 4.17 & 8.81 & $\mathrm{St}=0.05 \mathrm{P}_{\mathrm{g}}-0.14$ & 0.66 & 5.10 & 14.82 & $-1.23 e-07$ & $-3.79 \mathrm{e}-07$ \\
\hline S. viminalis & Combined & Dormant & $\mathrm{Th}=1.02 \mathrm{P}_{\mathrm{g}}-1.7$ & 0.60 & 1.39 & 0.90 & $\mathrm{St}=0.015 \mathrm{P}_{\mathrm{g}}+0.03$ & 0.97 & 2.10 & 5.02 & $-5.08 \mathrm{e}-08$ & $-1.27 e-07$ \\
\hline S. viminalis & & Global & $\mathrm{Th}=1.02 \mathrm{P}_{\mathrm{g}}-5.14$ & 0.74 & & & $\mathrm{St}=0.03 \mathrm{P}_{\mathrm{g}}+0.23$ & 0.49 & & & & \\
\hline S. caprea & SC I & & $\mathrm{Th}=0.91 \mathrm{P}_{\mathrm{g}}+4.86$ & 0.82 & & & $\mathrm{St}=0.05 \mathrm{P}_{\mathrm{g}}-0.13$ & 0.67 & & & & \\
\hline S.caprea & SC II & & - & - & & & $\mathrm{St}=0.06 \mathrm{P}_{\mathrm{g}}-0.04$ & 0.49 & & & & \\
\hline S. caprea & & Growing & $\mathrm{Th}=1.50 \mathrm{P}_{\mathrm{g}}-6.77$ & 0.83 & -1.03 & -13.23 & $\mathrm{St}=0.053 \mathrm{P}_{\mathrm{g}}-0.07$ & 0.58 & 8.25 & 45.50 & $-7.77 e-07$ & $-3.37 e-06$ \\
\hline $\begin{array}{l}\text { S.caprea } \\
\text { S. caprea }\end{array}$ & Combined & $\begin{array}{c}\text { Dormant } \\
\text { Global }\end{array}$ & $\begin{aligned} \mathrm{Th} & =0.84 \mathrm{P}_{\mathrm{g}}-0.11 \\
\mathrm{Th} & =0.91 \mathrm{P}_{\mathrm{g}}+4.86\end{aligned}$ & $\begin{array}{l}0.86 \\
0.82 \\
\end{array}$ & 2.61 & 6.51 & $\begin{array}{l}\mathrm{St}=0.14 \mathrm{P}_{\mathrm{g}}-1.05 \\
\mathrm{St}=0.05 \mathrm{P}_{\mathrm{g}}-0.10\end{array}$ & $\begin{array}{l}0.48 \\
0.61\end{array}$ & 12.37 & 49.64 & $-4.66 e-07$ & $-1.38 \mathrm{e}-06$ \\
\hline
\end{tabular}




\subsubsection{Drying conditions}

When compared with the fallow slope transect, the vegetated transect showed

161 significantly lower $\left(\chi^{2}=53.94, \mathrm{df}=1, \mathrm{p}<0.01\right)$ soil moisture and $\left(\theta_{v}\right.$; Fig. 6a-d) and

162 significantly higher matric suction $\left(u_{a}-u_{w}\right.$; Fig. 7a-d $)\left(\chi^{2}=52.07, \mathrm{df}=1, \mathrm{p}<0.01\right)$.

The soil moisture increased significantly with soil depth $(\mathrm{W}=6027, \mathrm{p}<0.01$;

164 Fig. 6a-d), and was, on average, $12.84 \%$ higher in the fallow transect when compared

165 with the vegetated one. The fallow transect showed significant differences in terms of

$166 \theta_{v}$ between the slope positions $\left(\chi^{2}=28.35, \mathrm{df}=3, \mathrm{p}<0.01\right)$ with the UC shown to be the

167 driest (Fig. $1 \mathrm{~b} ; \mathrm{W}=1284, \mathrm{p}<0.01$ ) position on the slope. The vegetated transect did not

168 show significant differences in soil moisture between the slope positions $\left(\chi^{2}=5.78\right.$,

$169 \mathrm{df}=3, \mathrm{p}=0.12)$.

170

Figure 6. Measured (points and crosses) and interpolated (lines) volumetric moisture content $\left(\theta_{\mathrm{v}}\right)$ time series for the fallow slope transect and willow-vegetated slope transect at two soil depths (300 mm and $400 \mathrm{~mm}$ b.g.l) and at four different slope locations (a) lower toe (LT) (b) upper toe (UT) (c) lower crest (LC) (d) upper crest (UC). Top and right-hand side axes: daily rainfall $\left(\mathrm{mm} \mathrm{d}^{-1}\right)$ time series.

over the monitoring period at all slope positions (Fig. 1b), $u_{a}-u_{w}$ (Fig. 7a-d) reached peaks of ca. $60 \mathrm{kPa}$. In the fallow transect, $u_{a}-u_{w}$ was well below $20 \mathrm{kPa}$ for most of the monitoring time and at all 4 slope positions, where saturation levels of suction (i.e. $0 \mathrm{kPa}$ ) were reached during the monitoring period (Fig. 7a-d). For both treatments, $u_{a^{-}}$ $u_{w}$ showed significant differences between slope positions (Willow: $\chi^{2}=27.89, \mathrm{df}=3$, $\mathrm{p}<0.01$; Fallow: $\chi^{2}=15.04, \mathrm{df}=3, \mathrm{p}<0.01$ ). UC (Fig. 1b) showed the lowest suction levels in the vegetated transect $(\mathrm{W}=342, \mathrm{p}<0.01)$. right-hand side axes: daily rainfall $\left(\mathrm{mm} \mathrm{d}^{-1}\right)$ time series 

$u_{w}$ under drying conditions are shown in Table 4.

4; Fig. 8a) was found at all slope positions for the fallow transect after fitting Eq.5

(Table 2) using the monitoring data (Figs. 6 and 7). Only the SWCC fitted for LC

(Fig. 1b) differed from the curves fitted for the other three slope positions (Fig. 8a). A statistically significant relationship between $u_{a}-u_{w}$ and $\theta_{v}$ was not encountered for the

194 vegetated slope transect (Fig. 8b). Consequently, the hydro-mechanical parameters for 195 the willow-vegetated soil could not be obtained. The mean $\alpha$ (Table 2) from the LT, 196 UT, and UC slope positions (Table 4) was used in Eq.1 (Table 2). To evaluate the 197 soil stress-state (Eq. 7; Table 2) under vegetation cover and drying conditions, the 198 value of $n$ (Table 2) was assigned arbitrarily (Table 4) in agreement with published 199 values for vegetated soil (Carminati et al., 2010). transect obtained at: LT - lower toe; UT - upper toe; LC - lower crest; and UC - upper crest slope positions.

4.2.2. Matric suction predictions

The plant-derived soil matric suctions under drying conditions were 204 successfully predicted using Eq. 1 (Fig. 7). No statistical differences were detected 205 between the observations and model predictions except for the LC position (Table 4). 
Table 4. Parameters value used in the implementation of Eqs. 1 and 7 (Table 1) for predicting plant-derived matric suctions, and the subsequent suction stress, under the scenarios of maximum (Max) and minimum (Min) atmospheric demand. Bottom part: goodness of fit (i.e. F-statistic and AIC) between predicted plant-derived matric suction time series and monitored field values. Slope positions: LT: lower toe; UT: Upper toe; LC: lower crest; UC: upper crest.

\begin{tabular}{|c|c|c|c|c|c|c|c|c|c|}
\hline \multirow[b]{3}{*}{ Parameter } & \multirow[b]{3}{*}{ Definition } & \multicolumn{4}{|c|}{ Fallow soil } & \multicolumn{4}{|c|}{ Vegetated soil } \\
\hline & & \multirow{2}{*}{\multicolumn{2}{|c|}{$\operatorname{Max}$}} & & & \multicolumn{2}{|c|}{ Salix viminalis } & \multicolumn{2}{|c|}{ Salix caprea } \\
\hline & & & & \multicolumn{2}{|c|}{ Min } & Max & Min & Max & Min \\
\hline$E_{u}$ & Potential daily evapotranspiration rate; $\mathrm{m} \mathrm{d}^{-1} \mathrm{~m}^{-2}$ & \multicolumn{2}{|c|}{-} & \multicolumn{2}{|c|}{-} & $6.28 \mathrm{e}-08$ & $1.96 \mathrm{e}-08$ & $6.38 \mathrm{e}-08$ & $1.99 \mathrm{e}-08$ \\
\hline$E_{t p}$ & Potential daily plant transpiration rate; $\mathrm{m} \mathrm{d}^{-1} \mathrm{~m}^{-2}$ & \multicolumn{2}{|c|}{-} & \multicolumn{2}{|c|}{-} & $3.97 \mathrm{e}-08$ & $1.23 \mathrm{e}-08$ & $5.12 \mathrm{e}-08$ & $1.59 \mathrm{e}-08$ \\
\hline$E_{s p}$ & Potential daily soil evaporation rate; $\mathrm{m} \mathrm{d}^{-1} \mathrm{~m}^{-2}$ & \multicolumn{2}{|c|}{$1.42 \mathrm{e}-11$} & \multicolumn{2}{|c|}{$4.42 \mathrm{e}-12$} & $1.83 \mathrm{e}-11$ & $5.71 \mathrm{e}-12$ & $1.00 \mathrm{e}-11$ & $3.13 \mathrm{e}-12$ \\
\hline$d_{x}$ & Evaporative soil depth; $m$ & \multirow{2}{*}{\multicolumn{4}{|c|}{$\begin{array}{c}0.13 \\
2.31 \mathrm{e}-08\end{array}$}} & \multirow{2}{*}{\multicolumn{4}{|c|}{$2.31 \mathrm{e}-08$}} \\
\hline \multirow[t]{2}{*}{$\tilde{K}(\theta)$} & Unsaturated hydraulic conductivity; $\mathrm{m} \mathrm{s}^{-1}$ & & & & & & & & \\
\hline & Slope position & LT & UT & LC & $\mathrm{UC}$ & LT & UT & $\mathrm{LC}$ & $\mathrm{UC}$ \\
\hline$\alpha$ & Inverse air-entry pressure; $\mathrm{kPa}^{-1}$ & 0.06 & 0.05 & 0.2 & 0.06 & \multicolumn{4}{|c|}{0.05} \\
\hline$n$ & Pore-size distribution parameter; unitless & 6.00 & 5.00 & 2.23 & 5.00 & \multicolumn{4}{|c|}{2.00} \\
\hline $\mathrm{R}^{2}$ & Coefficient of determination for SWCC & 0.90 & 0.74 & 0.70 & 0.73 & \multicolumn{4}{|c|}{-} \\
\hline F-statistic $(\mathrm{df}=15)$ & Variance test statistic from $u_{a}-u_{w}$ model validation & & & & & 0.91 & 2.62 & 4.58 & 0.92 \\
\hline p-value & Significance level from variance test & & & & & 0.86 & 0.07 & $<0.01$ & 0.87 \\
\hline AIC & Akaike information criterion from ARIMA & & & & & 115.18 & 132.21 & 141.07 & 90.56 \\
\hline
\end{tabular}


210 All of the studied time series were stationary on the basis of the autocorrelation tests.

211 The ARIMA models fitted for the LT and UC positions presented higher goodness of

212 fit (Table 4) than ???????.

4.3. Evaluation of willow hydrological effect on slope stability using the unified effective stress principle

well as between fallow and vegetated soil. These differences were mainly attributed to

221 the differences in the hydro-mechanical parameters between the fallow and willow-

223 While the infiltration as a piston flow tended to dramatically reduce the suction stress

224 (Figs. 9a-c), the stemflow-derived bypass infiltration did not significantly change the

225 soil stress-state conditions with respect to hydrostatic state (shown in Fig. 9d as grey

226 dashed line).

Figure 9. (a) Suction stress $\left(\sigma^{\mathrm{s}}\right)$ profiles produced by the hydrological mechanisms evaluated under wetting two wetting scenarios (S1 and S2) (b) Suction stress $\left(\sigma^{\mathrm{s}}\right)$ profiles produced by the hydrological mechanisms evaluated under wetting conditions (i.e. throughfall and stemflow) for S.viminalis and S.caprea for the growing season under the two wetting scenarios (S1 and S2) (c) Suction stress $\left(\sigma^{\mathrm{s}}\right)$ profiles for fallow soil under the two wetting scenarios (S1 and S2) (d) Suction stress $\left(\sigma^{\mathrm{s}}\right)$ profiles produced by the hydrological mechanism evaluated under drying conditions for S.viminalis, S.caprea (i.e. plant transpiration; Etp) and fallow soil (i.e. direct soil evaporation; Esp) under the two atmospheric demand scenarios (Max. Etp and Min. Etp); Dotted line: $\sigma^{\mathrm{s}}$ profile under drying conditions assuming non-composite material; Dashed line: hydrostatic $\sigma^{\mathrm{s}}$ profile (e) Factor of Safety (FoS) profiles under vegetated soil for the elected wetting and drying events (f) Factor of Safety (FoS) profiles under fallow soil for the selected wetting and drying events. FoS > 1.0 denotes a stable slope in engineering terms (Craig, 2004).

235 with the suction stress profiles (Figs. 9a-d). Drastic reductions in suction stress

236 resulted in instability zones (i.e. FoS $<1$ ) in the FoS profiles (Figs. 9e-f). The increase 
in suction stress under drying conditions (Fig. 9d) appeared to shift the FoS profiles towards values denoting stability (i.e. FoS $>1$; Figs. 9e-f) when compared with the wetting conditions. As a result of this, the FoS distribution showed significant differences between the wetting and drying conditions $\left(\chi^{2}=82.18, \mathrm{df}=1, \mathrm{p}<0.01\right)$, as well as between the fallow and vegetated soil $\left(\chi^{2}=11.75, \mathrm{df}=1, \mathrm{p}<0.01\right)$. FoS differences between the willow species were not detected under wetting or drying conditions. However, the FoS derived from the throughfall effect (Fig. 9e) showed significant differences under the heavy rain scenario $\left(\mathrm{S} 2 ; \chi^{2}=7.49, \mathrm{df}=1, \mathrm{p}<0.01\right)$. Under drying conditions, significant differences were observed between the maximum and minimum $E_{t p}$ scenarios $\left(\chi^{2}=19.13, \mathrm{df}=1, \mathrm{p}<0.01\right)$.

Values of FoS below unity were predicted for soil depths of $400 \mathrm{~mm}$ b.g.l and deeper (Figs. 9e-f). This outcome was due to the assumptions of soil strength (i.e. $\mathrm{c}=0$ $\mathrm{kPa}$ ) and a very steep slope (i.e. $\beta=45^{\circ}$ ) which highlighted the hydrological effect of Salix sp. under critical stability conditions. Under this setting (unrealistic for our study site with mean soil cohesion of $33 \mathrm{kPa}$ and mean slope gradient of $25^{\circ}$ ), the stress generated by the weight of the soil column counteracted the shear resistance provided by the angle of internal friction. The latter was not high enough to provide stable slope conditions in the absence of cohesion ( $\mathrm{Lu}$ and Godt, 2013), leading to the occurrence of failure zones in the FoS profiles (Figs. 9e-f).

\section{Discussion}

5.1. Quantification of the hydrological mechanisms of willow affecting slope stability under wetting and drying conditions

5.1.1. Wetting conditions: 

viminalis (Fig. 5a; Table 3) noticeably affected the amount of rain that eventually

264 reached and entered the ground. This effect was observed to be seasonal (Table 3; 265 Fig. 5a) due to foliage cover (Deguchi et al., 2006). However, under the heavy rainfall 266 scenario (i.e.. S2; see 3.3.1), the interception capacity decreased (Table 3) as a result 267 of the canopy saturation (van Dijk and Bruijnzeel, 2001). This suggests that under 268 heavy precipitation events, such as the ones normally triggering landslides (Sidle and 269 Bogaard, 2016), most of the rain will reach the ground. However, rainfall interception 270 can still be useful in regulating the water mass balance in the soil (Llorens and 271 Domingo, 2007), preventing the soil from reaching saturation moisture levels during 272 prolonged periods of gentle rain (i.e. typical meteorological conditions at our study 273 site) and, potentially improving the slope stability conditions (Lu and Godt, 2013). The throughfall regression model for Salix caprea predicted more throughfall 275 than the gross rainfall for the growing season (Table 3). This may result from dripfall 276 (Zimmermann and Zimmermann, 2014) - the rainwater that accumulates on leaves 277 and falls to the ground once the canopy has become saturated (van Dijk and 278 Bruijnzeel, 2001) - which would have been significant due to the fact that the 279 observed canopy storage capacity for $S$. caprea was rather low (see 4.1.1; Deguchi et 280 al., 2006). Dripfall patterns are likely to be random, as the architecture of tree 281 canopies is highly heterogeneous (e.g. Bohrer et al., 2009). As a result, a given 282 interception rain gauge may collect larger water volumes than originally expected. 283 This anomaly could be corrected by changing the setup approach to monitor a larger 284 canopy area (Zimmermann and Zimmermann, 2014). In our case, however, a broader 285 canopy area could not be taken for study due to the site operational difficulties (i.e. 286 steep and densely vegetated slope prone to instability) and the entwined canopies in 
the stand. Nonetheless, the method outlined here for evaluating throughfall for slopes under dense vegetated zones was shown to be feasible. Future studies should focus on addressing the indicated shortcomings to obtain reliable rainfall interception models in these environmental contexts.

The stemflow results (Figs. 5c-d; Table 3) indicated that the concentration of 292 water around the stem can be substantial (Liang et al., 2011; Levia and Germer, 293 2015). Stemflow differences observed between the studied species suggest that the canopy morphology (e.g. branch architecture, tree-crown spread) may also govern this 295 mechanism (Yuan et al., 2016). Stemflow water could be funnelled around the tree 296 base and enter the soil as a bypass flow (Liang et al., 2011) with potential effects on 297 the soil stress-state ( $\mathrm{Lu}$ and Godt, 2013). Thus, careful consideration of plant aerial 298 traits may help to highlight the intra-species differences in terms of stemflow (Levia 299 and Germer, 2015). In any case, the method presented here was shown to be viable 300 for quantifying the volumes of water concentrated around the stems of woody 301 vegetation growing on slopes. Our study has also shown that the stemflow process 302 deserves more attention in order to better understand the water cycle dynamics on 303 vegetated slopes (Levia and Germer, 2015).

\subsubsection{Drying conditions}

The plant-water uptake, assessed through the measurement of $\theta_{v}$ (Fig. 6a-d) and $u_{a}-u_{w}$ differences between vegetated and fallow soil over time (Fig. 7a-d), was

308 evident in all cases (Persson, 1995; Ng et al., 2013). This stresses the positive 309 hydrological effect of vegetation in terms of the soil water balance regulation in a 310 slope stability context (Stokes et al., 2008). The vegetation showed a pronounced 311 effect upon the increase of $u_{a}-u_{w}$ (Fig. 7a-d) and on the desaturation or drainage (i.e. 
$312 \theta_{v}$ increased with soil depth; Fig. $\left.6 \mathrm{a}-\mathrm{d}\right)$ of the soil profile, suggesting that vegetation

313 increases slope stability (Wilkinson et al., 2002). This effect appeared to be stronger

314 at the lower toe of the slope (Fig. 7a) which may have been due to a denser vegetation

315 cover at the slope toe in the willow-vegetated transect. The denser vegetation cover

316 may have been favoured by a more gentle slope gradient at the landslide deposition

317 zone (i.e. slope toe), where soil nutrients tend to accumulate (Walker et al., 2009;

318 Gonzalez-Ollauri and Mickovski, In Press). A denser plant cover could have led to a

319 higher plant-water demand (Jia et al., 2017) which, in turn, helped tomaintain higher 320 suction (Fig. 7a) and lower moisture levels (Fig. 6a) in the soil.

321 There appeared to be an effect of climate on the soil moisture dynamics (e.g.

322 Zhang et al., 2016) in our observations as both $u_{a}-u_{w}$ and $\theta_{v}$ were affected by changes

323 in precipitation patterns (Figs. 6 and 7) - soil input water from rainfall led to marked

324 decreases in $u_{a}-u_{w}$ and increases in $\theta_{v}$ as rain infiltrated into the soil profile. However,

325 this observation could not be fully quantified because of the relatively short

326 monitoring period, which we acknowledge to be a limitation of our study. A temporal

327 expansion of the study would help the evaluation the hydrological effect of vegetation

328 under different seasonal conditions (e.g. winter, when atmospheric demand of water is

329 low in temperate climates), and derivation of a clearer numerical relationship between

330 rainfall, $u_{a}-u_{w}$, and $\theta_{v}$.

5.2. Prediction of plant-derived matric suction under drying conditions

333 The plant-derived matric suction predictions (Fig. 7a-d) using Eq. 1 (Table 2) matched

334 well the monitoring (Fig. 7a-d) and fell within the range observed in situ. The

335 predictive capacity of our approach could be enhanced in the future by revising some

336 of the assumptions made to reduce the computational effort. For example, we 
considered a constant $K(\theta)$ (i.e. the one corresponding to the water content at field

338 capacity; Table 4) instead of allowing it to vary with the soil moisture overtime. 339 Additionally, the same $A c$ (Table 1) was considered for three of the four monitored 340 slope positions. Finally, $E_{t p}$ (Table 4) estimations can vary from approach to approach

341 (Li et al., 2016) and the required inputs are subject to many inaccuracies depending 342 upon the meteorological station from where they had been retrieved. The $E_{t p}$ 343 estimation was particularly sensitive to sunlight duration, which, at our site with 344 mainly overcast days, tended to be negligible and led to low estimation of $E_{t p}$. All of 345 these, together with the soil moisture buffering behaviour induced by plant roots (i.e. 346 upon drying the root system tends to hold more water, while upon wetting it tends to 347 remain drier than the surrounding bulk soil; Carminati et al., (2010), could explain the 348 time lags between predictions and observations (Fig. 7a-c). The original equation (Eq.2; Lu and Griffiths, 2006) predicted invariant (ca. $350 \quad 2.5 \mathrm{kPa}) u_{a}-u_{w}$ time series that were well below the in situ observations (Fig. 7a-d) 351 because it did not incorporate the effects of vegetation. The unsuccessful 352 determination of the hydro-mechanical parameters ( $\alpha$ and $n$ ) for vegetated soil (Fig. $3538 \mathrm{~b}$; Table 4) suggests that the relationship between plant, soil and water is more 354 complex than the one between soil and water alone. This supports the idea of plant355 soil composite materials (Thorne, 1990) behaving hydro-mechanically differently 356 from soil alone (Scanlan, 2009; Gonzalez-Ollauri and Mickovski, 2017). The 357 determination of $\alpha$ and $n$ could potentially have been obscured by either microscopic 358 or macroscopic issues. On the one hand, the release of root mucilage could have 359 altered the relationship between water content and matric potential in the root zone 360 (Read and Gregory,1997; Read et al., 2003). On the other, plant effects on the soil 361 structural properties (e.g. Bronick and Lal, 2005; Scholl et al., 2014) may have 
modified the hydrological behaviour of the soil (Liang et al., 2011). Further investigation should be carried out to confirm our observations and develop new,

364 robust models that are able to predict $u_{a}-u_{w}$, as well as SWCC, under the effect of 365 vegetation, instead of assigning new and different hydro-mechanical parameters to 366 vegetated soils alone (Scanlan, 2009; Carminati et al., 2010; Leung et al., 2015).

367 Moreover, an extension of the monitoring period, as indicated before, and inclusion of 368 different plant species, would potentially clarify the feasibility of the suggested 369 approach. Nonetheless, we believe that our model opens up an exciting possibility for 370 the assessment of the plant-derived hydrological effect in a slope stability context, 371 given the high relevance of $u_{a}-u_{w}$ to the soil stress-state (Vanapalli et al., 1996; Lu and 372 Likos, 2004; Gonzalez-Ollauri and Mickovski, 2017).

5.3. Evaluation of willow hydrological effect on slope stability using the unified effective stress principle Overall, the unified effective stress principle (UES) was shown to be adequate for capturing the hydrological effect of vegetation on slope stability (Fig. 9). Our results support the hypothesis that plant-water uptake is the main hydrological mechanism by which vegetation can improve slope stability (Figs. 9d and e; Stokes et 380 al., 2014). Under drying conditions, the soil strength (i.e. $\sigma^{s}$; Fig. 9d) improved 381 substantially with respect to the wetting (Figs. 9a-c) and hydrostatic (dashed dark grey 382 line in Fig. 9d) conditions. However, this effect is expected to be markedly seasonal 383 in temperate climates where the atmospheric water demand is expected to be 384 negligible in winter (Wever et al., 2002). The differences between the two willow 385 species upon drying (Figs. 9d and e) reflect the assumption made with regard to the 386 effect of canopy features (i.e. Ac and LAI; Table 1; Eqs.1, 3 and 4; Table 2) on the soil 
stress-state and slope stability. A wider canopy with broader leaves (i.e. higher LAI; Table 1) led to higher transpiration rates (Table 4; Allen et al., 1998), which increased the soil strength (Fig. 9d) and slope stability (Fig. 9e). Our results (Fig. 9d) reflect the differences in water flow rates upon drying (i.e. plant transpiration vs. soil evaporation; Table 4) as well as the hydro-mechanical differences between plant-soil composites and soil materials (Table 4). If alternative, and lower $n$ values were not given to vegetated soil (Table 4), the hydrological effect of willow on the soil stressstate would have been negative in respect of the fallow soil upon drying (Fig. 9d) which would have been contradictory to the field observations (e.g. Simon and Collison, 2002). Thus, the hydro-mechanical change provoked by the presence of 397 vegetation in the soil is expected to have considerable hydrological implications for 398 slope stability (e.g. Gonzalez-Ollauri and Mickovski, 2017). The quantification of 399 these emergent plant-soil composite properties is still a major knowledge gap that needs further investigation (e.g. Scanlan, 2009; Carminati et al., 2010). Under wetting conditions (Figs. 9a-c), vegetation effect on slope stability was 402 minimal (Fig. 9e-f). This outcome stresses the mechanical role of vegetation (i.e. soil403 root reinforcement; Stokes et al., 2008; Gonzalez-Ollauri and Mickovski, 2016) under 404 critical hydrological conditions of slope stability. The FoS profiles (Fig. 9e) would 405 not have presented failure zones (i.e. FoS $<1$ ) under wetting conditions if the 406 apparent root cohesion had been included in the analysis (Wu et al., 1979; Mickovski 407 et al., 2009; Gonzalez-Ollauri and Mickovski, 2014). Yet, the effect of plant aerial 408 features on the belowground hydrological dynamics became evident with the 409 implementation of UES. The investigation of shortcomings discussed for Salix caprea 410 in Section 5.1 led to the prediction of a negative hydrological effect on the soil-stress 411 state (Figs. 9a-b) with respect to the fallow soil (Fig. 9c). However, Salix viminalis 
showed a positive ability to intercept rainfall (Table 3; Fig. 5a). This resulted in a

413 shallower wetting front (Figs. 9a and b) with respect to the fallow soil (Fig. 9c). The

414 latter was particularly noticeable during the growing season and under the heavy

415 rainfall scenario (Fig. 9b). As a result, the location of the potential slope failure plane

416 was shown to be shallower under $S$. viminalis with respect to the fallow soil (Figs. 9e-

417 f). This effect, albeit small, could make a difference in terms of slope stability and in 418 terms of the soil volume wasted during landslide episodes (Gonzalez-Ollauri and 419 Mickovski, 2016).

420 The bypass flow (Table 2) triggered by stemflow (Table 3; Figs. 5c-d; Liang 421 et al., 2011) did not produce soil stress-state changes (Fig. 9a-b) with respect to the 422 hydrostatic conditions (Fig. 9d). As a result, the stemflow had a negligible effect on 423 slope stability (Fig. 9e). Nonetheless, we stress, once again, that stemflow deserves 424 further attention (Levia and Germer, 2015) in studies focusing on slope stability with 425 the use of vegetation. Such studies should focus on the plant traits favouring the 426 formation of stemflow (Yuan et al., 2016) and on the clarification of the features of 427 the infiltration process triggered by stemflow (Liang et al., 2011).

6. Conclusions

This study provides a novel and reproducible framework that sets the basis for

433 effective evaluation of the hydrological effect of vegetation on slope stability and to 434 shed more light on the hydrological mechanisms involved. In light of our observations 435 and findings, it can be concluded that: 
- When compared to fallow soil, willow had a noticeable hydrological effect on the soil. This was seen in differences in the recorded time series for $u_{a}-u_{w}$ and $\theta_{v}$, revealing the potential soil desaturation effect of vegetation and its subsequent positive effect on slope stability. consideration upon using UES for the evaluation of the hydrological effect of vegetation on rainfall-induced landslides. We encourage testing the framework presented herein under different environmental settings (i.e. climate, vegetation, soil hysteretical conditions, seasons, etc.). 
463 The authors thank to Catterline Brae Action Group (CBAG) for site access and

464 logistical support. Special thanks to Pieter voor de Porte for supplying meteorological 465 data. The help of students funded by international programmes, Leonardo Gentile and 466 Gabriel Maraslis (Science Without Borders students) is greatly acknowledged. We 467 are grateful to Elizabeth Mittell for language and style editing. We also acknowledge 468 the useful comments and suggestions from the Editors and two anonymous referees 469 that helped us to enhance this manuscript. This research project was funded by a $\mathrm{PhD}$ 470 scholarship awarded by the School of Engineering and Built Environment at the 471 Glasgow Caledonian University (S1340554).

\section{$472 \quad$ References}

474 Allen, R. Pereira, L., Raes, D., Smith, M., 1998. Crop evapotranspiration guidelines for computing crop water requirements. FAO Irrigation and drainage paper No 56.

Bohrer, G., Katul, G.G., Walko, R.L., Avissar, R., 2009. Exploring the effects of microscale structural heterogeneity of forest canopies using large-eddy simulations. Boundary-Layer Meteorology, 132, 351-382.

Bordoni M., Meisina C., Vercesi A., Bischetti G.B., Chiaradia E.A., Vergani C., Chersich S., Valentino R., Bittelli M., Comolli R., Persichillo M.G., Cislaghi A., 2016. Quantifying $124,3-22$. 
Brooks, R. and Corey, A., 1964. Hydraulic properties of porosus media (Vol.3). Hydrology Papers-Colorado State University. Fort Collins, Colorado, US.

Carminati, A., Moradi, A.B., Vetterlein, D., Vontobel, P., Lehmann, E., Weller, U., Vogel, H. and Oswald, S.E., 2010. Dynamics of soil water content in the rhizosphere. Plant Soil, 332, 163-176

Collison, A. and Anderson, M.G., 1996. Using combined slope hydrology/stability model to identify suitable conditions for lanslide prevention by vegetation in the humid tropics. Earth Surface Processes and Landforms, 21, 737-747.

Cowpertwait, P. S. P. and Metcalfe, A. V., 2009. Introductory time series with R. 495 Springer, Doerdrecht, The Netherlands.

496 Craig, R., 2004. Craig's Soil Mechanics $7^{\text {th }}$ Edition. E and FN Spon. London, UK 497 Deguchi, A., Hattori, S., and Park, H., 2006. The influence of seasonal changes in canopy structure on interception loss: Application of the revised Gash model. Journal of Hydrology, 318, 80-102.

Duan, L., Huang, M., Zhang, L., 2016. Differences in hydrological responses for different vegetation types on steep slope on the Loess Plateau, China. Journal of Hydrology, 537, 356-366.

503 Gonzalez-Ollauri, A. and Mickovski, S.B., 2014. Integrated model for the hydromechanical effects of vegetation against shallow landslides. EQA, 13, 35-59.

505 Gonzalez-Ollauri, A. and Mickovski, S. B., 2016. Using the root spread information of pioneer plants to quantify their mitigation potential against shallow landslides

508 Gonzalez-Ollauri, A. and Mickovski, S.B., 2017. Plant-soil reinforcement response 509 under different soil hydrological regimes. Geoderma, 285, 141-150. 
510 Gonzalez-Ollauri, A. and Mickovski, S.B., In Press. Shallow landslides as drivers for 511 slope ecosystem evolution and biophysical diversity. Landslides, DOI: $10.1007 / \mathrm{s} 10346-017-0822-\mathrm{y}$

513 Fell, R, Ho, K.K.S., Lacasse, S., Leroi, E., 2005. A framework for landslide risk assessment and management. In: Hungr, Fell, Couture and Eberhardt (eds). Landslide risk management. Taylor and Francis Group, London.

516 Head, K. H. and Epps, R. J., 2011. Manual of Soil Laboratory Testing: Permeability. Shear Strenght and Compressibility Tests (Vol. 2). CRC Press, Boca Raton, US.

519 Jia, X., Shao, M., Zhu, Y., Luo, Y., 2017. Soil moisture decline due to afforestation across the Loess Plateau, China. Journal of Hydrology, 546, 113-122.

521 Köppen, W., 1884. The thermal zones of the Earth according to the duration of hot, moderate amd cold periods and the impact of heat on the organic world. Meteorol. Z. 1, 215-226.

524 Kramer, P. and Boyer, J.S., 1995. Water relations of plants and soils. Elsevier 525 Science, San Diego, US.

526 Laio, F., 2006. A vertically extended stochastic model of soil moisture in the root zone. Water Resources Research. 43 (W02406).

528 Laio, F., D’Odorico, P., Ridolfi, L., 2006. An analytical model to relate the vertical

529 root distribution to climate and soil properties. Geophys. Res. Lett., 33, L18401.

530 Leung, A.K., Garg, A., Ng., C.W.W., 2015. Effects of plant roots on soil-water 531 retention and induced suction in vegetated soil. Engineering Geology, 193, 183197. 
533 Levia, D.F. and Germer, S., 2015. A review on stemflow generation dynamics and 534 stemflow-environment interactions in forests and shrublands. Review of 535 Geopgysics, 53, 673-714.

536 Li, S., Kang, S., Zhang, L., Zhang, J., Du, T., Ding, R., 2016. Evaluation of six 537 potential evapotranspiration models for estimating crop potential and actual 538 evapotranspiration in arid regions. Journal of Hydrology, 543, 450-461.

539 Liang, W., Kosugi, K. and Mizuyama, T., 2011. Soil water dynamics around a tree 540 on a hillslope with or without rainwater supplied by stemflow. Water Resources $541 \quad$ Research, 47 (W02541).

542 Llorens, P. and Domingo, F., 2007. Rainfall partitioning by vegetation under 543 Mediterranean conditions. A review of studies in Europe. Journal of Hydrology, $544 \quad 335,37-54$.

545 Lu, N. and Likos, W. J., 2004. Unsaturated Soil Mechanics. John Wiley and Sons, 546 Hoboken, US.

547 Lu, N. and Giffiths, D., 2006. Profiles of steady-state suction stress in unsaturated 548 soils. J. Geotech. Geoenviron. Eng., 130 (10), 1063-1076.

549 Lu, N., Godt, J.W., 2008. Infinite slope stability under steady unsaturated seepage $550 \quad$ conditions. Water Resources Research., 44 (W11404).

551 Lu, N., and Godt, J., 2013. Hillslope Hydrology and Stability. Cambridge University 552 Press, New York, US.

553 Lu, N., Godt, J. and Wu, D., 2010. A closed-form equation for effective stress in 554 unsaturated soil. Water Resources Research, 46 (5), 1-14.

555 McVicar, T.R., van Niel, T.G., Li. L.T., Wen, Z.M., Yang. Q.K., Li, R., Jiao, F., 556 2010. Parsimoniously modelling perennial vegetation suitability and identifying 557 priority areas to support China's re-vegetation program in the Loesss Plateau: 
Matching model complexity to data availability. Forest Ecology and Management, 259(7), 1277-1290.

560 Mein, R. and Larson, C., 1973. Modeling infiltration during steady rain. Water $561 \quad$ Resources Research, 9 (2), 384-394.

562 Mickovski, S., Hallet, P., Bransby, M., Davis, M., Sonnenberg, R., and Bengough, A., 563 2009. Mechanical Reinforcement of Soil by Willow Roots: Impacts of Roots Properties and Root Failure Mechanisms. Soil Sci. Soc. Am., 73 (4), 1276-1285.

Muukkonen, P. and Makipaa, R., 2004. Biomass equations for european tree: addendum. Silva Fennica, 40 (4), 763-773.

567 Neitsch, S., Arnold, J., Kiniry, J., Williams, J., 2011. Soil and Water Assessment Tool: Theoretical documentation. Water Resources Institute Technical Report No

570 Ng., C.W.W., Woon, K.X., Leung, A.K., Chu, L.M., 2013. Experimental 571 investigation of induced suction distribution in grass-covered soil. Ecological $572 \quad$ Engineering, 52, 219-223.

573 Nordh, N.E. and Verwijst, T., 2004. Aboveground biomass assessments and first 574 cutting cycle production in willow (Salix sp.) coppice - a comparison between destructive and non-destructive methods. Biomass Bioenergy, 27, 1-8.

576 Norris, J. S. et al., 2008. Slope Stability and Erosion Control: Ecotechnological

577 Solutions. Springer, Doerdrecht, The Netherlands.

578 Paternoster, R., Brame, R., Mazerolle, P., and Piquerom A. R., 1998. Using the 579 correct statistical test for the equality of regression coefficients. Criminology,

581 Person, G., 1995. Willow stand evapotranspiration simulated for Swedish soils. 582 Agricultural Water Management, 28,271-293. 
583 Powel, D., 2005. How to measure a big tree. USDA, Forest Service.

584 Priestley, C., and Taylor, R., 1972. On the Assessment of Surface Heat Flux and 585 Evaporation Using Large-Scale Parameters. Monthly Weather Review. 100 (2), $586 \quad 81-92$

587 Raz-Yaseef, N., Rotenberg, E. and Yakir, D., 2010. Effects of spatial variations in soil 588 evaporation caused by tree shading on water flux paeritioning in a semi-arid pine 589 forest. Agricultural and Forest Meteorology, 150, 454-462.

590 Read, D. and Gregory, P.J., 1997. Surface tension and viscosity of axenic maize and $591 \quad$ lupin mucilages. New Phytologist, 157, 315-326.

592 Read, D., Bengough, A., Gregory, P., Crawford, J., Robinson, D., and Scrimgeour, C., 593 2003. Plant roots release phospholipid surfactants that modify the physical and $594 \quad$ chemical properties of soil. New Phytologist, 157, 315-236.

595 Roderick, M.L., Sun, F., Lim, W.H., Farquhar, G.D., 2014. A general framework for 596 understanding the response of the water cycle to global warming over land and 597 ocean. Hydrology and Earth System Sciences, 18(5), 1575-1589.

598 Rodriguez-Iturbe, I. and Porporato, A. 2004. Ecohydrology of Water-Controlled 599 Ecosystems. Cambridge University Press, New York, US.

600 R Core Team, 2015. R: A language and environment for statistical computing. Viena, 601 Austria: R Foundation for Statistical Computing URL: http://www.R-project.org 602 Savabi, M.R. and Williams, J.R., 1995. Water balance and percolation. In: Flanagan, 603 D.C. and Nearing, M.A. (eds), USDA-Water Erosion Prediction Project: 604 Hillslope and watershed model documentation. NSERL Report No. 10.. USDA605 ARS National Soil Erosion Research Laboratory, West Lafayette, US.

606 Scanlan, C.A., 2009. Porcesses and effects of root-induced changes to soil hydraulic 607 properties. $\mathrm{PhD}$ Thesis, University of Western Australia. 
Scholl, P., Leitner, D., Kammerer, G., Loiskandl, W., Kaul, H. and Bodner, G., 2014. Root induced changes of effective 1D hydraulic properties in a soil column. Plant Soil. 381:193-213.

Shukla, M.J., 2014. Soil Physics. An Introduction. CRC Press, London, UK.

Sidle, R.C. and Bogaard, T.A., 2016. Dynamic earth system and ecological controls of rainfall-induced landslides. Earth-Science Reviews, 159, 275-291.

Simon, A. and Collison, J., 2002. Quantifying the mechanical and hydrological effects of riparian vegetation on streambank stability. Earth Surface Processes and Landforms, 27, 527-546.

Stokes, A., Douglas, G., Fourcaud, T., Giadrossich, F., Gillies, C., Hubble, T., et al., 2014. Ecological mitigation of hillslope instability: ten key issues facing researchers and practitioners. Plant Soil , 377, 1-23.

Stokes, A., Norris, J., van Beek, L., Bogaard, T., Cammeraat, E., Mickovski, S., et al., 2008. How vegetation reinforces soil on slopes. In J. Norris, A. Stokes, S. Mickovski, E. Cammeraat, R. van Beek, B. Nicoll, et al., Slope Stability and Erosion Control: Ecotechnological Solutions (pp. 65-116). Springer, Dordrecht, The Netherlands.

Tardio, G., Gonzalez-Ollauri, A., Mickovski, S.B., 2016. A non-invasive preferential root distribution analysis methodology from a slope stability apporach. Ecological Engineering, 97, 46-57.

Thorne, C.R., 1990. Effects of vegetation on riverbank erosion and stability. In: Thornes, J. B. (Ed.), Vegetation and Erosion (pp. 125-143). John Wiley and Sons 
631 Vanapalli, S. K., Fredlund, D. G., Pufahl, D. E., Clifton, A. W., 1996. Model for the 632 prediction of shear strength with respect to soil suction. Can. Geotech. J. 33:379$633 \quad 392$

634 van Dijk, A.I.J.M. and Bruijnzeel, L., 2001. Modelling rainfall interception by 635 vegetation of variable density using an adapted anylitical model. Part I: Model 636 description. Journal of Hydrology, 247, 230-238

637 van Genuchten, M., 1980. A closed-form equation predicting hydraulic conductivity 638 of unsaturated soils. Soil Sci. Soc. Am. J., 44, 892-898.

639 Vergani, C. and Graf, F., 2016. Soil permeability, aggregate stability and root growth: 640 a pot experiment from a soil bioengineering perspective. Ecohydrology, 9, 830$641 \quad 842$

642 voor de Poorte, P., 2011. Retrieved 7 24, 2015, from PEDROX, live weather from $643 \quad$ Catterline: http://www.pedrox.com

644 Walker, L. R., Velazquez, E. and Shiels, A.B., 2009. Applying lessons from 645 ecological succession to the restoration fo landslides. Plant Soil, 324, 157-168.

646 Wever, L.A., Flanagan, L.B. and Carlson, P.J., 2002. Seasonal and interannual 647 variation in evapotranspiration, energy balance and surface conductance in a

649 Wilkinson, P. L., Anderson, M. G., Lloyd, D. M. 2002. An integrated hydrological 650 model for rain-induced landslide prediction. Earth Surface Processes and $651 \quad$ Landforms. 27, 1285-1297.

652 Wilkox, R. R. and Keselman, H. J., 2003. Modern robust data analysis methods: 653 measures of central tendency. Psychol. Methods 8(3):254-274.

654 Wu, H. M., 1979. Strength of tree roots and landslides on Prince of Wales Island, 655 Alaska. Canadian Geotechnical Journal. 16 (1), 19-33. 
656 Yuan, C., Gao, G., Fu, B., 2016. Stemflow of a xerophytic shrub (Salix psammophila)

657 in northern China: Implications for beneficial branch architecture to produce

658 stemflow. Journal of Hydrology. 539, 577-588.

659 Zhang, D-H., Li, X-R., Zhang, F., Zhang, Z-S, Chen, Y-L., 2016. Effects of rainfall 660 intensity and intermittency on woody vegetation cover and deep soil moisture in 661 dryland ecosystems. Journal of Hydrology, 543, 270-282.

662 Zimmermann, A. and Zimmermann, B., 2014. Requirements for throughfall 663 monitoring: The roles of temporal scale and canopy complexity. Agricultural and $664 \quad$ Forest Meteorology, 189-190, 125-139.

665 


\section{FIGURE 1}

\section{N56.98 E-2.21 Catterline Bay}
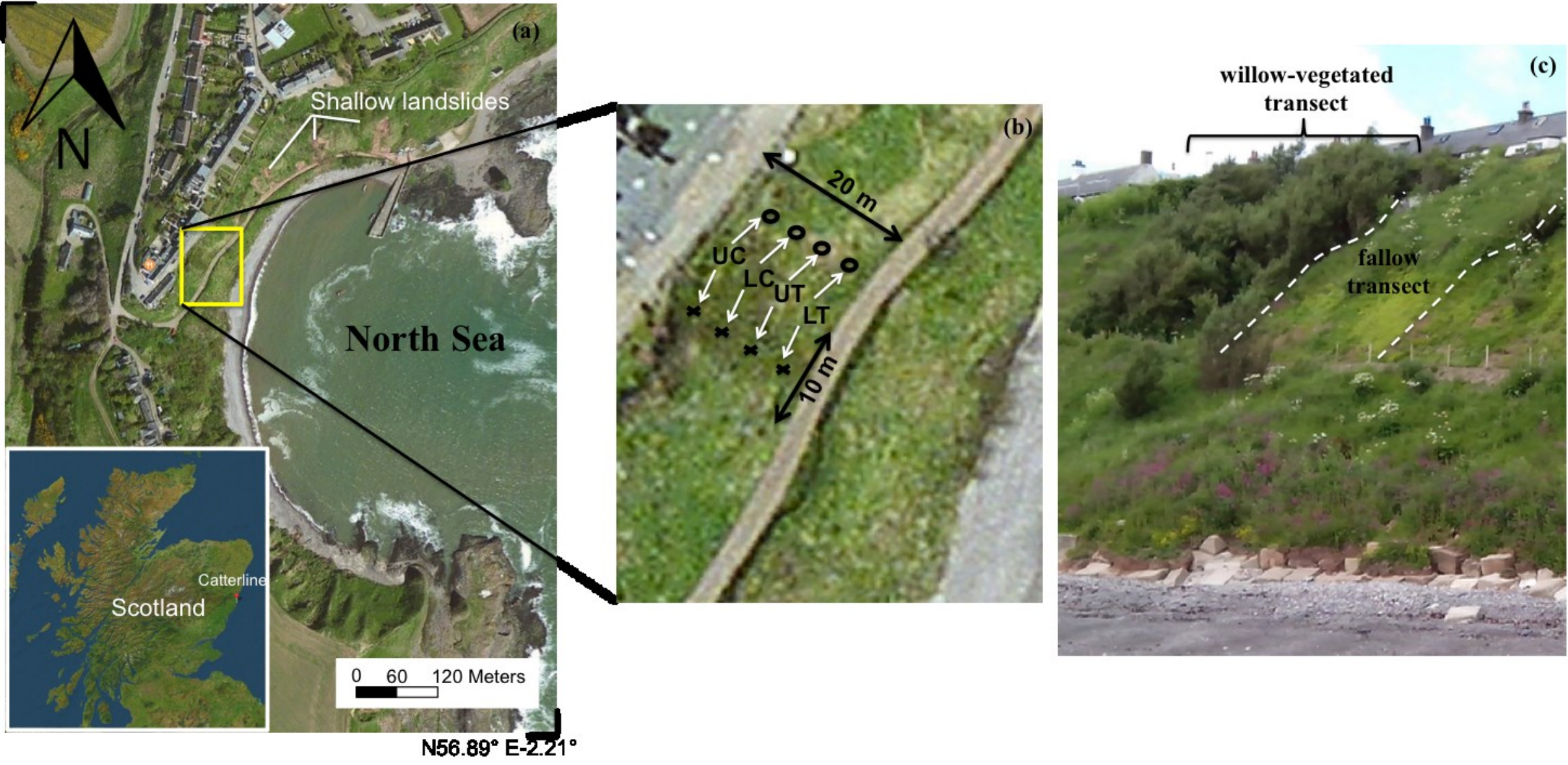
FIGURE 2

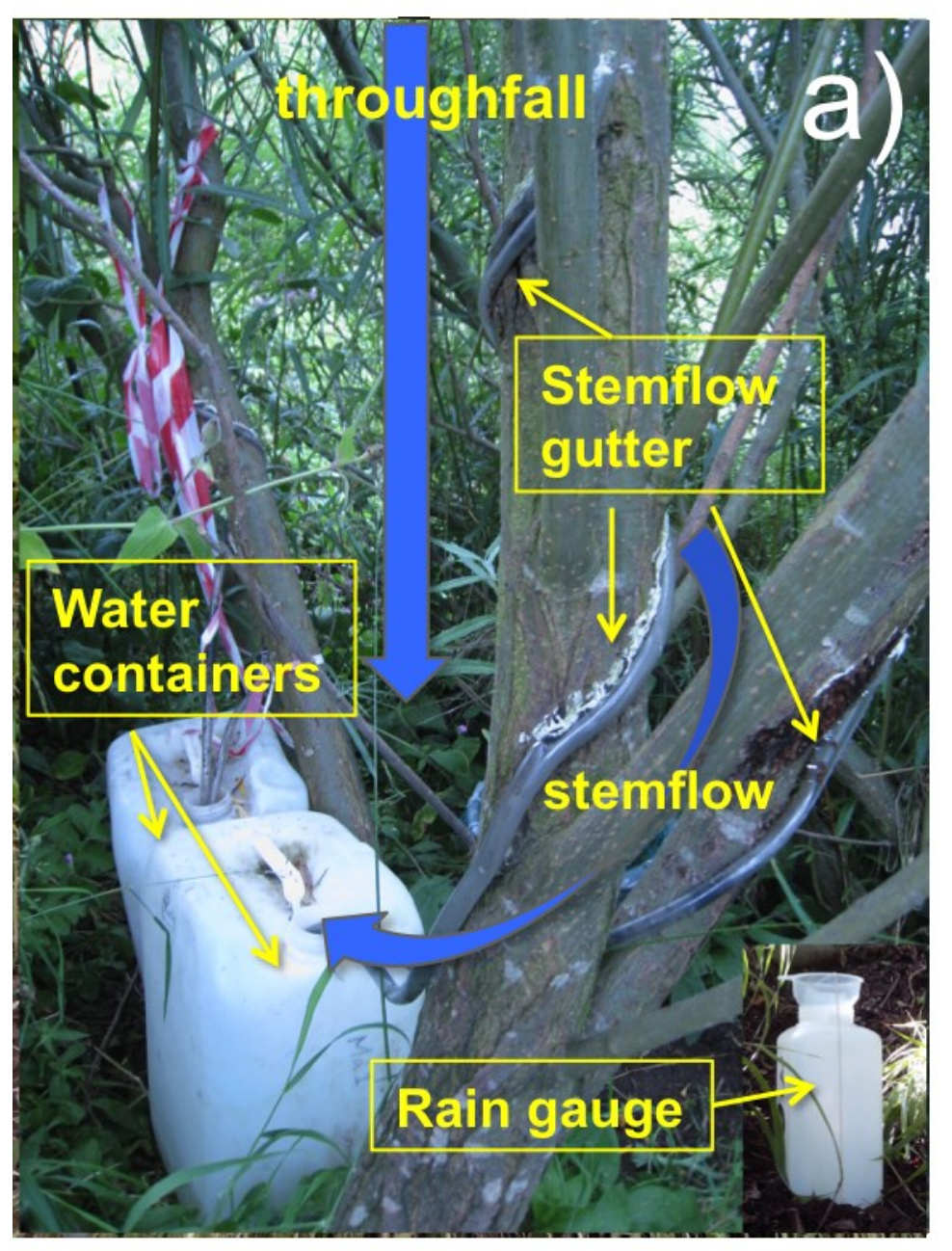

wetting

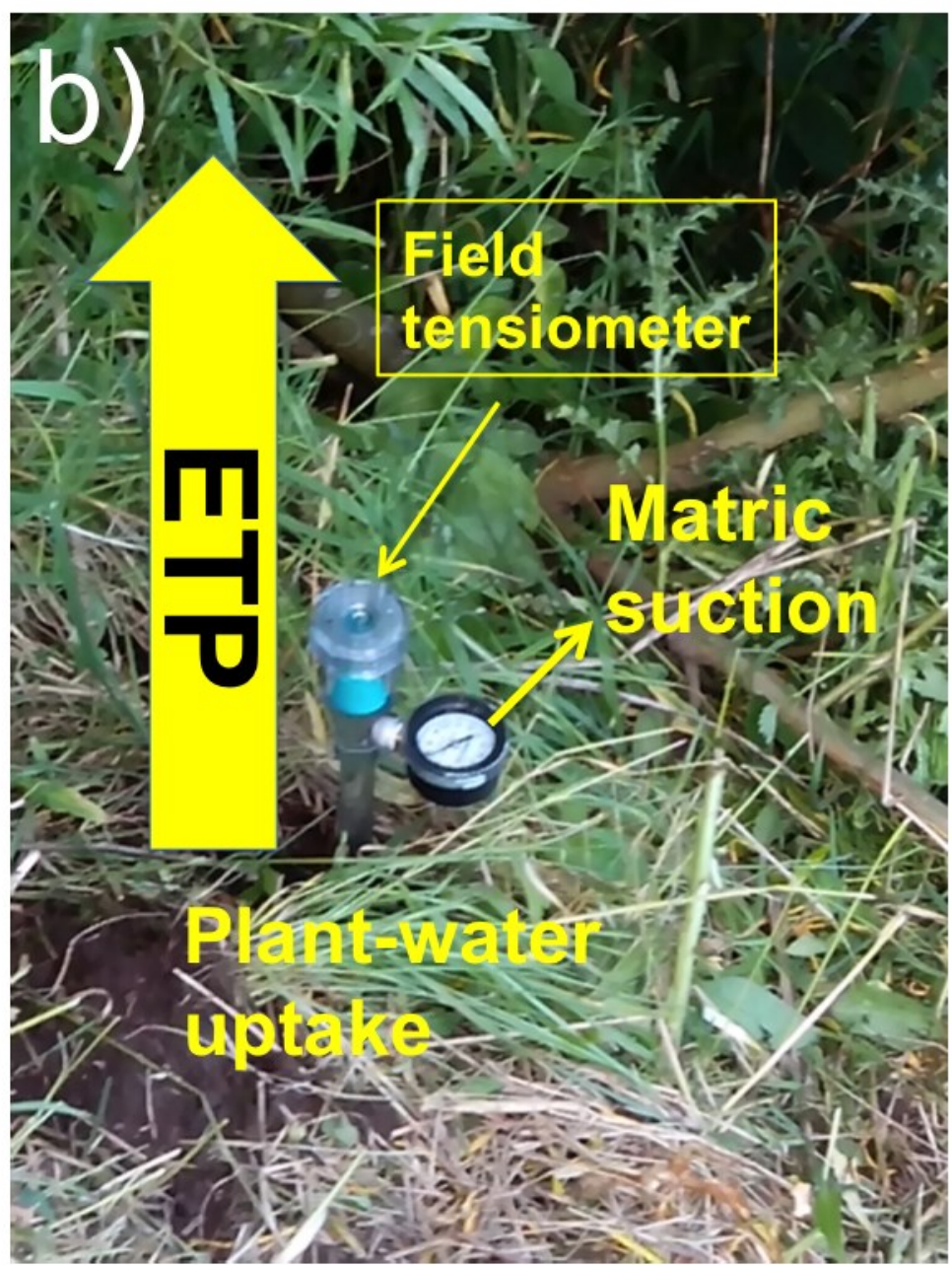

drying 
FIGURE 3

668

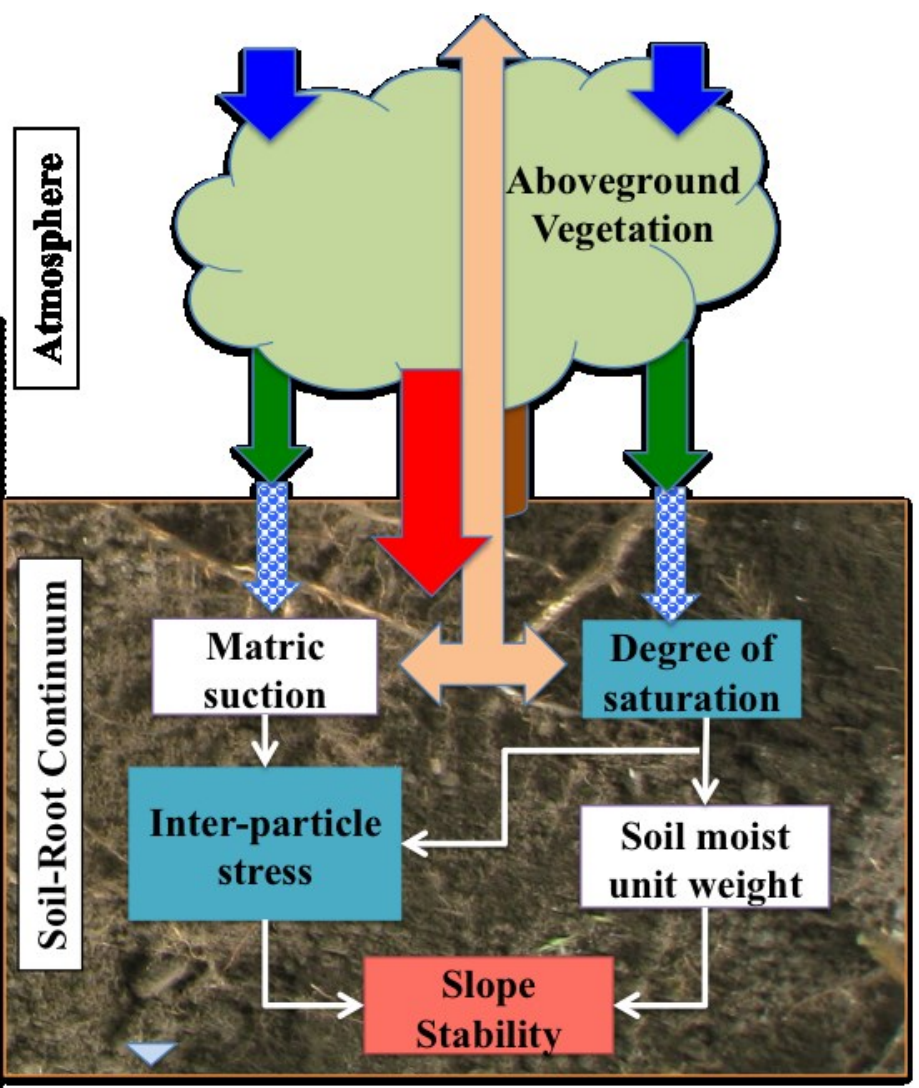




\section{FIGURE 4}

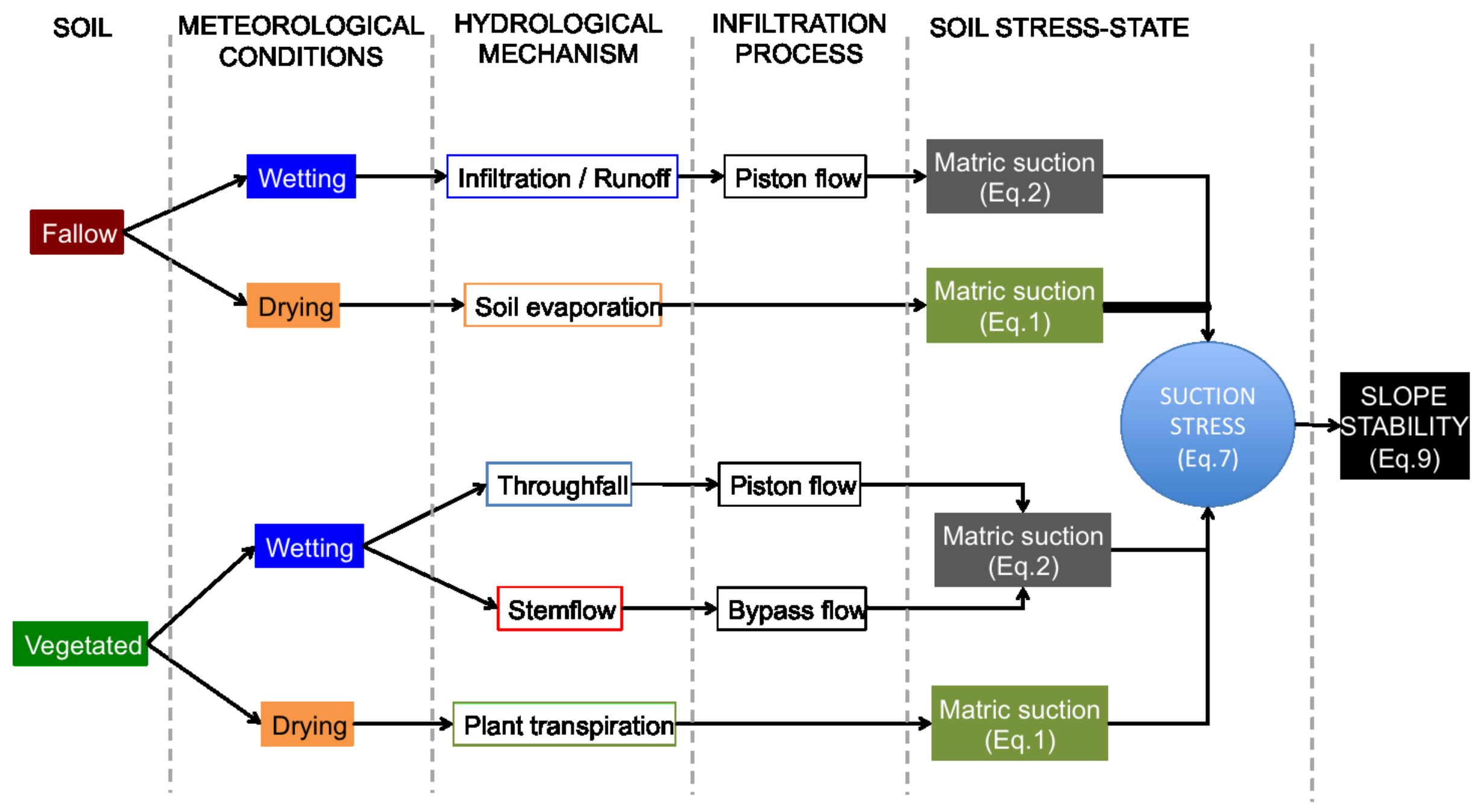



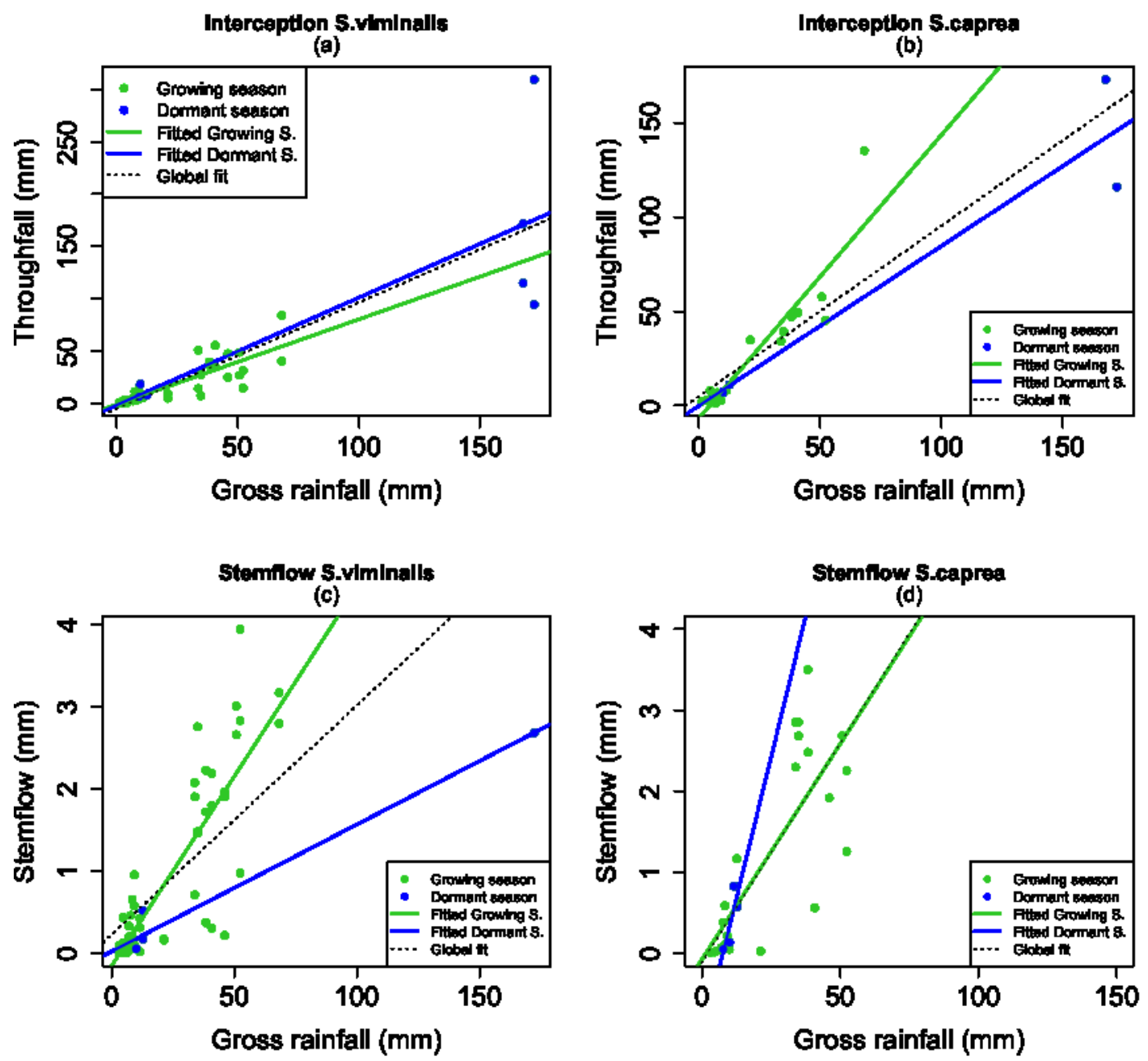
FIGURE 6

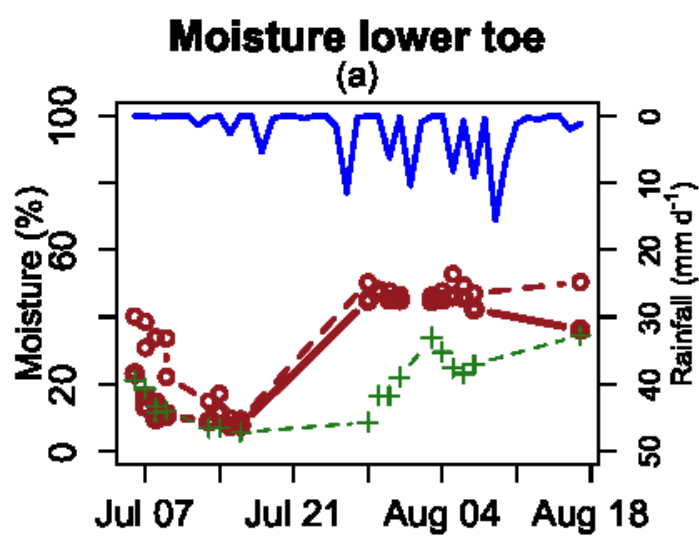

Day

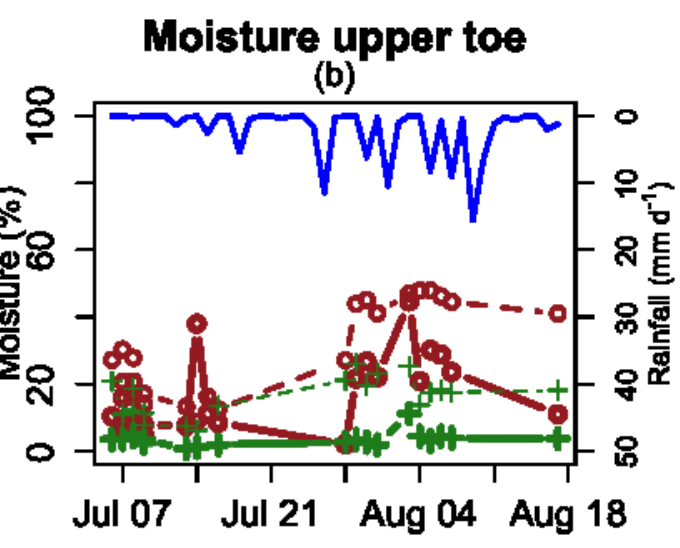

Day

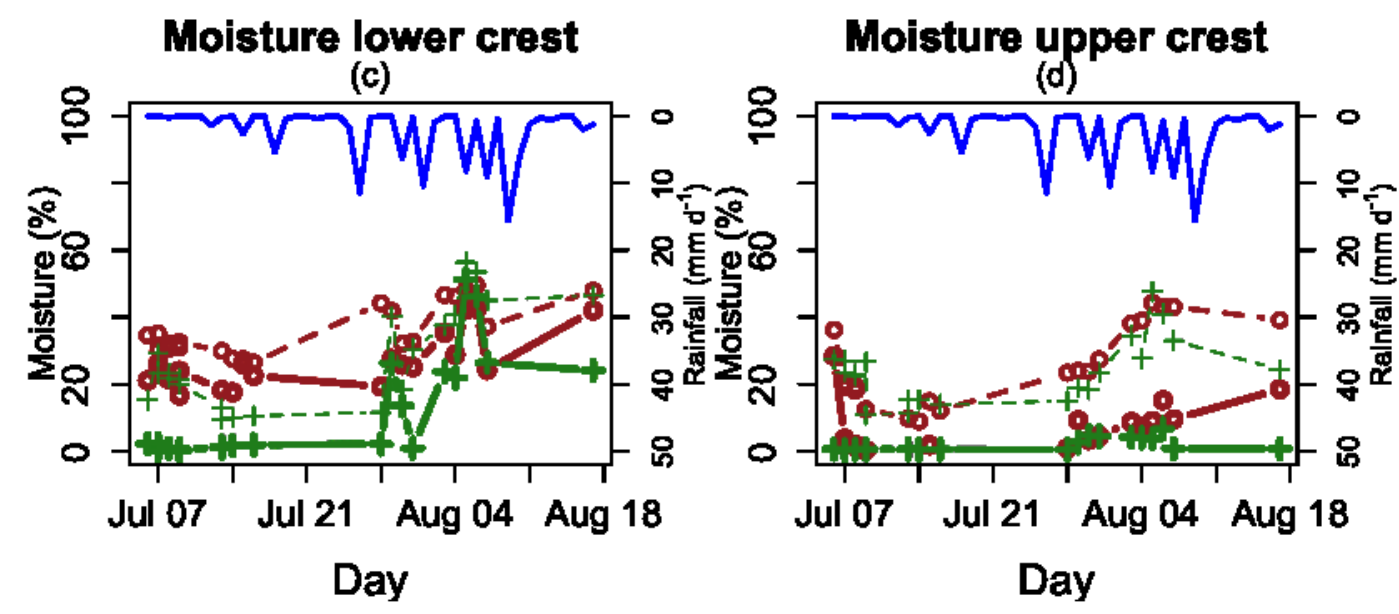

Fallow-300mm-o- Fallow-400mm - Wilow-300mm-+- Wilow-400mm — Precipitation

673

674

675

676

677

678

679

680

681 
FIGURE 7
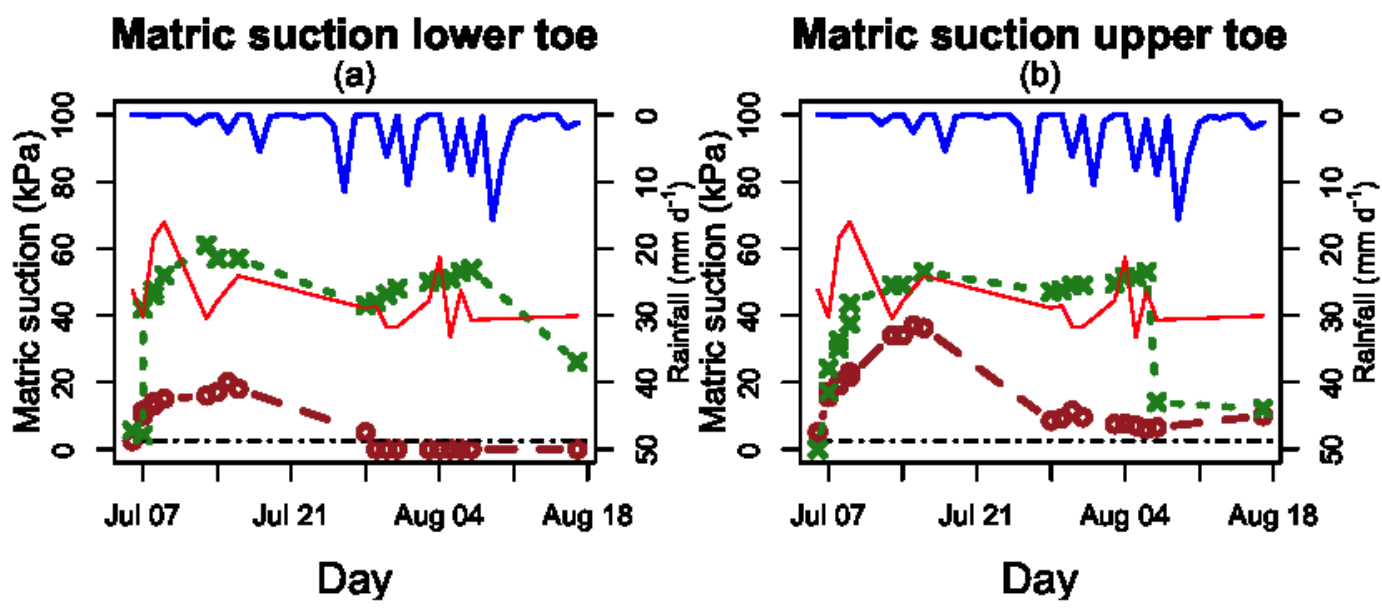

Matric suction lower crest

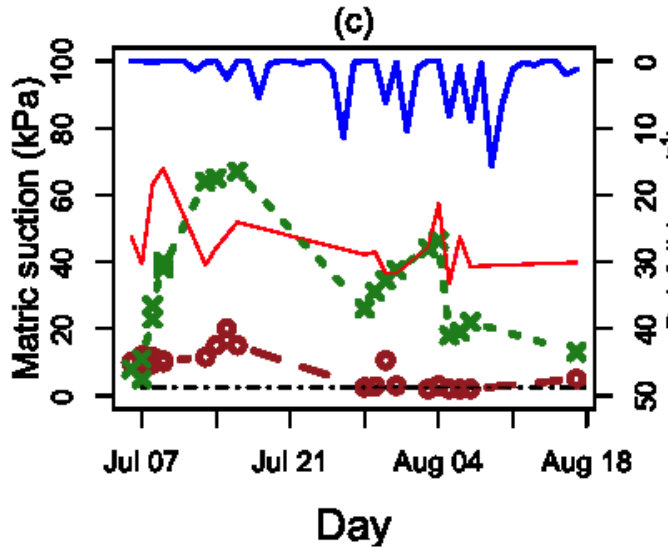

Matric suction upper crest

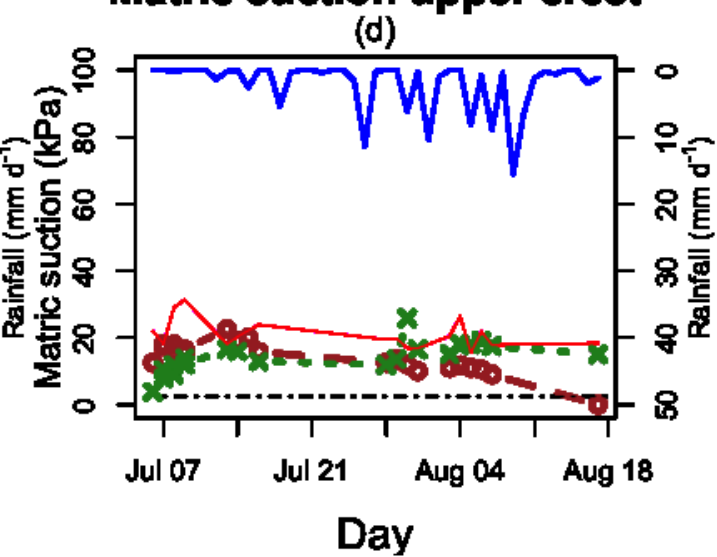

-o- Fallow $\quad *$ Willows $\quad$ Precipitation---- Model $1 \quad$ Model 2


FIGURE 8
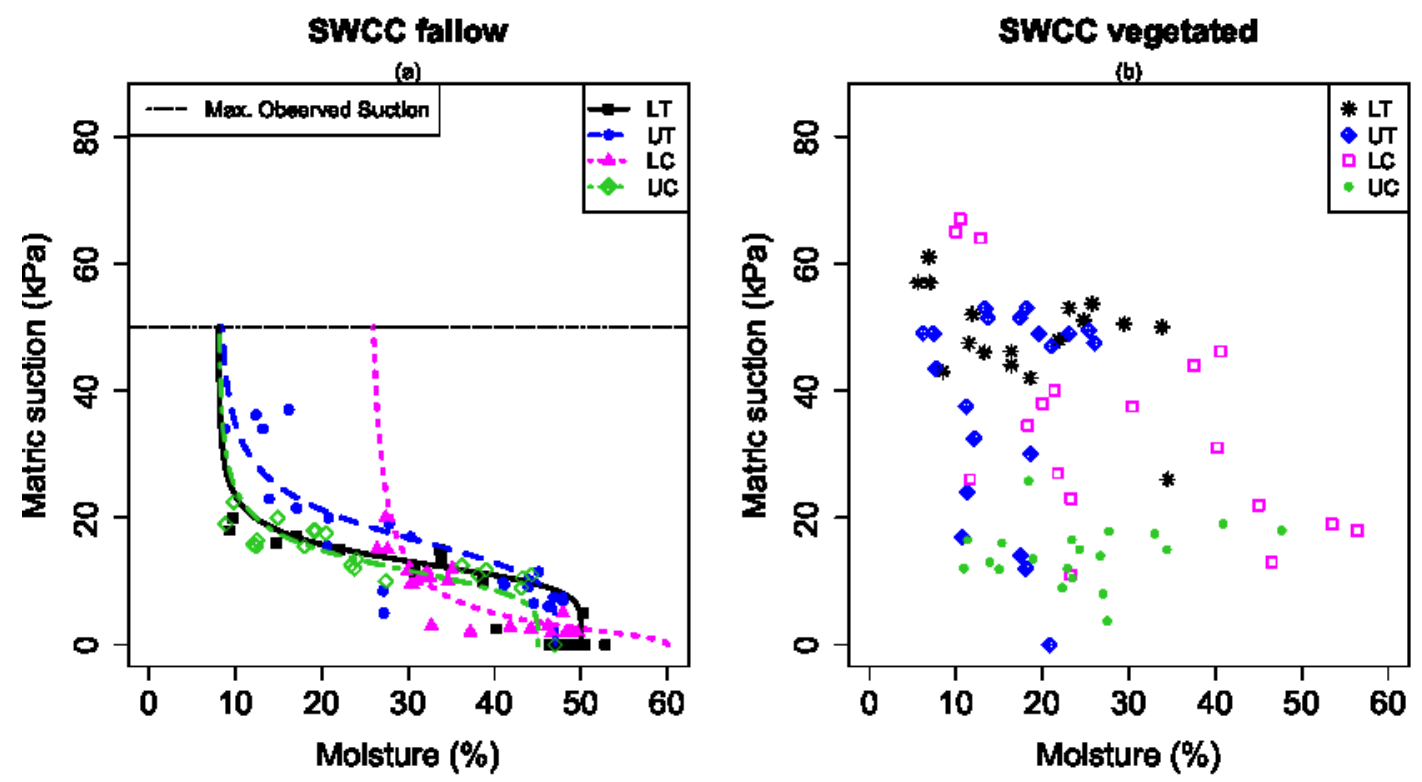

683 
FIGURE 9
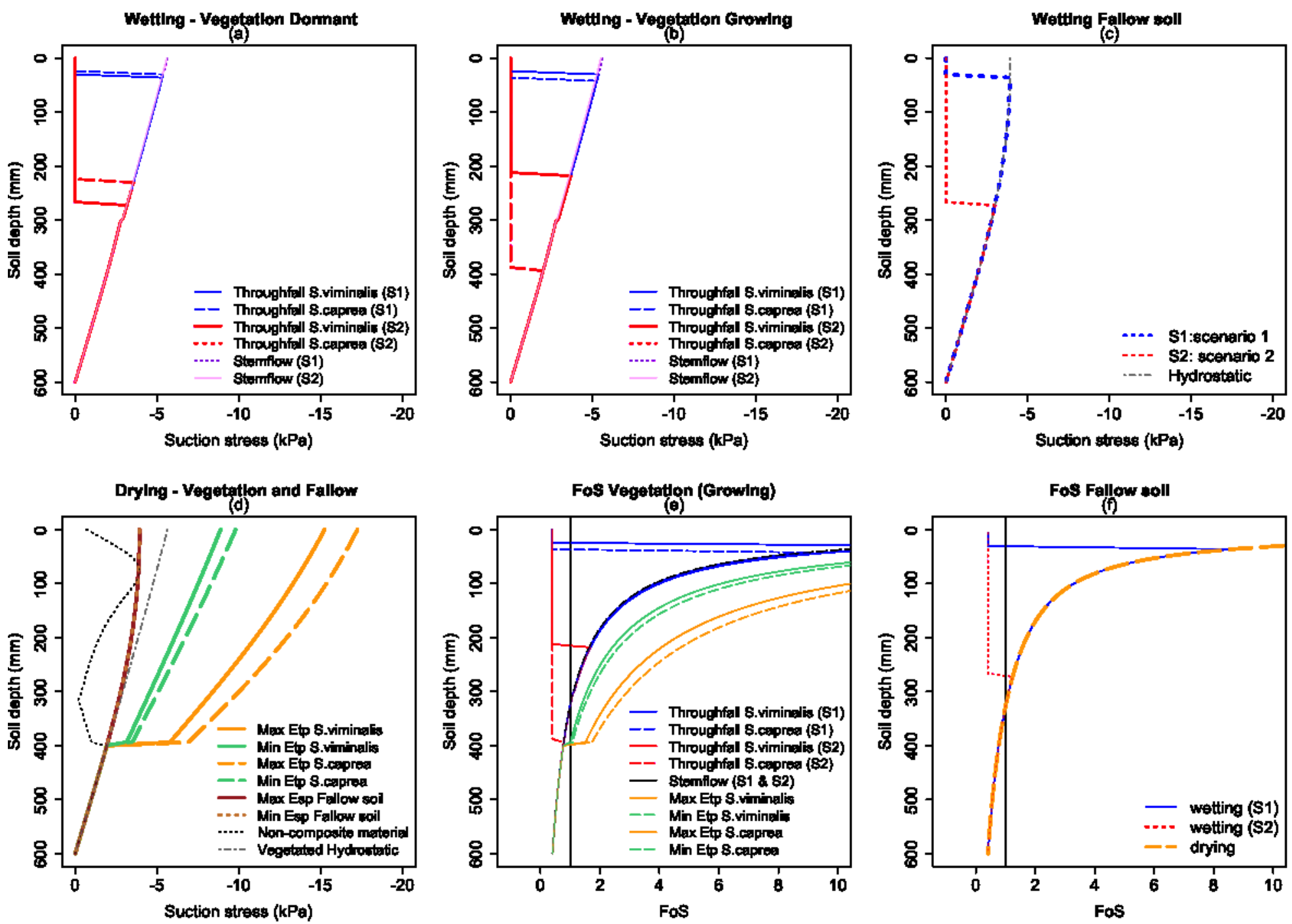
